\title{
Uluslararası B2B E-Pazarlama Gaziantep Ayakkabı Sektörüne Yönelik Bir Araştırma
}

\author{
Uğur YILDIZHAN*, Gülçimen YURTSEVER**
}

ÖZ

Çalışmada Gaziantep ayakkabı sektöründe üretim yapan firmaların uluslararası e-pazarlama yöntemi uygulama durumları araştırılmıştır. Gaziantep ayakkabı sektörünün uluslararası e-pazarlama sorunlarının belirlenmesi ve sektör için uluslararası e-pazarlama yol haritasının çıkarılmasına yardımcı olmak amaçlanmıştır. Bu amaç doğrultusunda Gaziantep ayakkabı sektöründe üretim yapan ihracatçılar birliğine kayıtll 17 firma ile nitel araştırmalarda sıklıkla kullanılan yüz yüze görüşme tekniği uygulanmıștır. Görüşmelerden elde edilen veriler MAXQDA veri analiz programı ile analiz edilmiştir. Elde edilen verilerin analizi sonucunda Gaziantep ayakkabı sektörünün uluslararası e-pazarlama sorunlarına yönelik firmaların içsel faktörler ve dışsal faktörler temaları altında 6 adet kategori oluşturulmuştur. Firmaların uluslararası e-pazarlama sorunlarına yönelik 429 adet kodlama yapılmıştır. Araştırmanın sonucunda ise Gaziantep ayakkabı sektörünün uluslararası B2B e-pazarlama sorunları ve çözüm önerileri sunulmuştur.

Anahtar Kelimeler: Uluslararası, B2B, E-pazarlama, İçsel Faktörler, Dışsal Faktörler

JEL Sinıflandırması: M3, M31

\section{International B2B E-Marketing a Research For Gaziantep Footwear Sector}

\begin{abstract}
In the study, the application status of international e-marketing method of the companies producing in Gaziantep shoe sector was investigated. It is aimed to identify the international e-marketing problems of Gaziantep shoe industry and to help create an international e-marketing road map for the sector. For this purpose, face to face interview technique, which is frequently used in qualitative research, was applied with 17 companies registered in the exporter union in Gaziantep shoe industry. The data obtained from the interviews were analyzed with the MAXQDA data analysis program. As a result of the analysis of the data obtained, 6 categories were created under the themes of internal and external factors of companies for the international e-marketing problems of Gaziantep shoe industry. 429 coding was done for companies' international e-marketing problems. As a result of the research, international B2B emarketing problems and solution suggestions of Gaziantep shoe industry are presented.
\end{abstract}

Keywords: International, B2B, E-marketing, Internal Factors, External Factors

JEL Classification: M3, M31

Geliş Tarihi / Received: 13.02.2020 Kabul Tarihi / Accepted: 07.05.2020

\footnotetext{
*yildizhanugur@ hotmail.com, ORCID: 0000-0001-7588-1998.

** Prof. Dr., Uşak Üniversitesi, İIBF, İşletme Bölümü, gulcimenyurtsever@gmail.com, ORCID:0000-0003-04840261.
} 


\section{GíRiş}

Dünya genelinde 2016 yılında 1,61 milyar kişinin internet üzerinden yapmış oldukları alışverişlerde ayakkabı ve malzemeleri en çok satın alınan ürünler içerisinde yer almaktadır (ILO, 2018:28). Dünya genelinde 2018 yllinda internet üzerinden yapılan ticaret hacmi ise işletmeden tüketiciye (B2C) 3,8 trilyon dolar, işletmeden işletmeye (B2B) 23,9 trilyon dolar olmuştur (WTO, 2018). Sürekli gelişen bilgi teknolojileri ile birlikte tüm dünyada internet üzerinden yapılan ticaretin popüler olarak kullanılmas1 sonucunda uluslararasi ticarette epazarlama tekniğinin uluslararası pazarlama teknikleri arasında üst sıralara taşımaktadır (Kuşat, 2016:692).Gelişmekte olan ülkeler arasında yer alan Türkiye'deki işletmeler teknolojiyi pazarlamada yeteri kadar kullanmamaktadırlar (Kaplan, 2015:145). Ayakkabı sektöründeki en büyük sorunlardan birisi pazarlama sorunudur ve sektörün gelişmesi bat1 ülkelerine yapılan ihracatın artmasına bağlıdır (Yaşar, 2018: 29). Sektördeki firmalar üretim kapasitelerinin tamamını kullanmamaktadırlar (GTB, 2017:23). Türkiye ayakkabı sektöründe fason üretim sebebiyle markalı ihracat oranı düşüktür (Çakıroğlu Başar, 2013: 269). Sektörde pazarlamaya yönelik araştırmalar yok denecek azdır (GTO, 2011:15). Deri ve ayakkabı sektöründeki firmalar için online ticaret uluslararası rekabet ve ihracatın arttırılmasında önemli bir rol oynamaktadır. Sektördeki firmalar derhal e-pazarlama konusunda hazırlıklarını yaparak ve e-pazarlama faaliyetinde bulunmalıdırlar (Yamamoto, vd., 2009:184).Bu açıklamalar bağlamında tüketici taleplerinde ve klasik pazarlama yöntemlerinde gerçekleşen değişiklerle birlikte uluslararası epazarlama yapmak firmalar için bir ihtiyaçtan çok zorunluluk haline gelmektedir.

Yaptığımız çalışmada firmaların uluslararası e-pazarlama tekniğini kullanmasında etkili olan içsel faktörleri ve dışsal faktörleri hakkında sorular yöneltilerek görüşmeler yapılmıştır. Yapılan görüşmeler sonucunda Gaziantep ayakkabı sektörünün uluslararası e-pazarlama tekniğini kullanma durumu ve e-pazarlama sorunlarını ortaya çıkarmak amaçlanmıştır. Yapılan görüşmelerin analizinden sonra Gaziantep ayakkabı sektöründeki firmalar için uluslararası epazarlama yol haritası çıkarılarak Gaziantep ayakkabı sektörünün ihracatının artırılmasına yol gösterilmeye çalışılmıştır.

\section{ULUSLARARASI B2B (IŞLETMEDEN ISSLETMEYE) E-PAZARLAMA}

Genel olarak B2B (İşletmeden İşletmeye); tedarikçiler, distribütörler, acenteler ve müşterileri oluşturan diğer firmaların etkileşimi olarak tanımlanmaktadır (Fauska vd., 2013:44). Firmaların internet üzerinden hizmet ve ürünlerini gerçekleştirmesi işlemine (B2B) e-ticaret modeli denmektedir (Akçi ve Göv, 2015:416). B2B e-ticaret uygulanması yüksek zorluğa sahip bir sistem olmas1 nedeniyle B2B e-ticaret yapmak isteyen KOBI'lerin makul bir olgunluk ve hazırlık düzeyine ulaşmış olması gerekir (Janom vd., 2014:71). Tüketici ürünleri üreten firmaların çoğu ürünlerini perakende veya toptancılara satmak zorundadır. B2B ticari pazarın tüketici pazarından farklılıkları; ürünlerin niteliği ve karmaşıklığı, sanayi talebi doğası ve çeşitliliği, az sayıda müşteri ve müşteri başına büyük hacimler, uzun ömürlü müşteri tedarikçi ilişkileridir (Kotler ve Pfoertsch, 2006: 20-21). B2B e-pazarlama yönteminden firmalar ihtiyaçlarını tedarikçi firmanın web sitesinden ya da üye olduğu e-pazaryerlerinden temin etmektedirler. B2B e-pazaryerleri KOBI'lerin küresel pazarlama yapabilmeleri için firsatlar sunarak mevcut müşterilerini korumalarını ve yeni müssteriler kazanmalarını sağlamaktadırlar (Chong, vd, 2011:4). İşletme alıcıları satın alma işleminde teknik ve ekonomik düşünerek alım kararı verdikleri için tüketici davranışındaki duygusal ve dürtüsel tarafını hedef alan pazarlama faaliyetleri B2B pazarlama için çok etkili değildir (Ponomarenko, 2018:5). Bu açıklamalar neticesinde KOBİ'ler B2B e-pazarlama yöntemini kullanarak büyük firmalardan bağımsız ve daha az maliyetlerle ürün ve hizmetlerini küresel olarak pazarlayabilirler. 


\section{ULUSLARARASI B2B E-PAZARLAMA İÇSEL YÖNETIMM FAKTÖRLERİ}

Firmaların başarılı bir uluslararası e-pazarlama yapabilmesi içsel faktörler için güçlü bir teknolojik alt yapı ve organizasyona ihtiyaçları vardır (Eid vd., 2006:203). Firmaların uluslararası e-pazarlama yöntemini uygulayabilmesi için firmaların içsel faktörleri uluslararası epazarlamada en önemli başarı faktörlerini oluşturmaktadır (Kuşat, 2016:697). B2B e-pazarlama hazırlık düzeylerinin ölçülmesinde firmaların iç ve dış organizasyon faktörlerinin tanımlanması kritik öneme sahiptir (Janom vd., 2014:73).

\subsection{E-Pazarlama Stratejisi}

Stratejik pazarlama planı olan firmalar, e-pazarlama yarışında daha avantajlıdırlar (Malinen, 2013:II). Pazarlama planı, pazarlama çabalarını yönlendirmek ve koordine etmek için merkezi bir araçtır (Kotler ve Keller, 2012:36). Firmaların uygulayacakları stratejik süreç modeli çok önemlidir. Firmalar e-pazarlama planı hazırlarken strateji geliştirme ve uygulamasını tüm faaliyetlerini kapsayacak bir yol izlemelidirler (Panomarenko, 2018:17).Internet pazarlama stratejisinin odak noktası, kanalın mevcut pazarlama stratejilerini desteklemek, güçlü yanlarını nasıl kullanacaklarını ve zayıf yönlerini nasıl yönetecekleri ve çok kanallı bir pazarlama stratejisinin parçası olarak diğer kanallarla birlikte nasıl kullanacakları hakkındaki kararlardır (Chaffey, vd., 2006:152-153). Stratejik bir planlama yapan yönetici firmanın e-ticaret için güçlü ve zayıf yönlerini tespit etmek için SWOT (Güçlü Yönler, Zayıf Yönler, Fırsatlar, Tehditler) analizini yapmalıdır (Strauss ve Frost, 2014:50). Firmaların başarılı bir e-pazarlama stratejisi uygulayabilmeleri için üst yönetimin desteği, organizasyon yapısı ve teknolojik alt yapıları önemli bir rol oynamaktadır. E-iş uygulamalarının kullanımı firmanın üst yönetiminin desteğiyle doğrudan ilişkilidir (Sapkiris ve Vlachopoulou, 2015:3-4). Pazarlama stratejisi açısından bakıldığında üst yönetimin desteği, stratejik hedeflerin belirlenmesi ve mevcut pazarlama stratejisi ile e-pazarlama stratejisinin birleştirilmesi firmaların e-pazarlama stratejisi için hayati önem teşkil etmektedir (Eid, vd, 2006:202). İnternet için hedef belirleme, yöneticilerin, internetin kendi endüstrileriyle gelecekteki durumu hakkındaki görüşüne dayanmaktadır (Chaffey, vd., 2006:168-169). Stratejik planların çoğu seçilen hedef ve stratejilerin mantığını belirtir. Firmanın kurumsal kaynaklarını yöneten üst düzey yönetimin desteğini kazanmaya çalışan tek bir e-iş projesi özellikle önemlidir (Strauss ve Frost, 2014:50).Üst yönetimin e-ticaret yöntemleri için aldıkları kararları uygulayabilmek firmanın organizasyon yapısının kullanılabilir olmasına bağlıdır (Janom vd., 2014:75). Stratejik planlama firmanın organizasyon sınırları içerisinde gerçekleşir ve bir firmanın organizasyonu politikaları ve kurum kültüründen oluşur. "Kurum kültürü̈; bir organizasyonu karakterize eden paylaşılan deneyimler, hikayeler, inançlar ve normlar olarak tanımlanabilir"' (Kotler ve Keller, 2012:45). Firmaların organizasyon yapıs1 bilgi sistemlerinin etki ve öneminin farkında olmalıdır (Laudon ve Price Laudon, 2012:8182).1990'lı yıllara kadar firmalar iletişimlerini posta ve telefon ile kurmaktayken günümüz teknolojisi ile ağ ve internet üzerinden daha hızlı bir şekilde iletişim kurabilmektedirler (Laudon ve Price Laudon, 2012:247). Teknolojinin gelişmesiyle birlikte internet üzerinde çevrimiçi küresel ticaret platformu oluşmuş ve bu platform her ölçekte firma için büyük firsatlar sunmaktadır (Chaffey, vd., 2006:488). İnternet firmalara milyonlarca tüketiciden oluşan küresel bir ortam ve çok düşük operasyonel maliyetler sunmaktadır (Laudon ve Traver, 2014:712). Firmaların e-pazarlamada rekabet üstünlüğü sağlayabilmeleri için ITC (Bilgi İletişim Teknolojileri) kullanma konusunda duyarlı olmalı ve teknolojik alt yapılarını geliştirmelidirler (Eid, vd., 2006:203). 


\subsection{Fonların Kullanılabilirliği}

E-pazarlama yöntemini kullanmak isteyen firmalar için teknolojik yeniliklerden faydalanmak firmalara rekabet avantaj1 sağlar. Çevrimiçi müşteri deneyimi ve kişiselleştirme tekniği için tescilli yazılım ve donanım teknolojisi kullanılmalı ve ayrıca firmaların arama motoru reklamı, popüler sitelerde banner reklamı ve e-posta pazarlaması yapabilmesi için büyük fonlara ihtiyaçları vardır (Chaffey, vd., 2006:116). Firmaların e-pazarlama yöntemini kullanmaları için uzman ve vasıflı personellere ihtiyaç duyarlar ancak piyasada bu konuda uzman ve vasıflı personellerin kısıtlı olması sebebiyle mevcut personelin eğitimi ya da uzman ve vasıflı personel temini için önemli mali kaynaklar sağlamalıdırlar (Sapkiris ve Vlachopoulou, 2015:3). Bu açılamalar neticesinde firmaların e-pazarlama teknolojisi ve bu teknolojileri kullanacak personeller için mali kaynak ayırması e-pazarlama yöntemini kullanmak için gerekli olan önemli bir faktördür.

\section{3. Örgütsel E-Hazırlık}

Firmaların e-hazırlığı ve teknolojilerin benimsenmesi; pratik ve teorik bilgiler, yüksek motivasyonlu satış gücü, pazarlama ve bilgi teknolojileri uzmanları arasında etkin işbirliği, teknoloji altyapısının geliştirilmesine yönelik iç odaklanma firmanın e-hazırlığı ve teknolojilerin benimsenmesi diğer tüm faktörleri belirleyen en önemli faktörlerdir (Skudiene, 2014:118-119). E-ticaret konusunda üst düzey yönetim ve çalışanlar arasında öz-yeterlik, motivasyon, ihtiyaç, yetenek ve beklentiler geliştirmek için motivasyon geliştirme programları sağlanmalı ve eticaretine yönelik olumlu alg1 ve tutumlar geliştirilmedir (Janom, 2014:77). Bu açıklamalar neticesinde firmaların e-pazarlama konusunda örgütsel hazırlığı ve motivasyonu firmaların başarılı bir e-pazarlama yapabilmesi için örgütsel e-hazırlıkları firmaların karşısına önemli bir faktör olarak çıkmaktadır.

\section{ULUSLARARASI B2B E-PAZARLAMA DIŞSAL YÖNETIM FAKTÖRLERİ}

Uluslararası e-pazarlama yönetimde etkili olan diş çevresel faktörler firmaların internet pazarlama stratejisi gelişimini göstermektedir. Dış çevresel faktörler, şirket içindeki şirket altyapısının doğal bir uzantısıdır; duyarlı ve iyi organize edilmiş iç süreçler olmadan dış çevresel faktörlerin bir etkisi olmayacaktır (Eid,vd., 2006:204). Firmaların uluslararası e-pazarlama yöntemini kullanmalarında firmaların içsel faktörlerin önemi oldukça önemli olmakla birlikte iç organizasyonu e-pazarlamaya uygun olmayan firmalar diş çevreler tarafindan gerçekleştirilen organizasyonlardan faydalanmakta da başarısız olurlar.

\subsection{Destekleyen Endüstriler}

Firmaların B2B e-pazarlama yöntemlerini destekleyen telekomünikasyon endüstrisi, finans kuruluşları, lojistik firmaları, güven sağlayıcılar, bilişsim endüstrisi ve danışmanlık hizmetleri ile ilgili sektörlerin B2B e-pazarlama için sağladıkları hizmetler firmaların epazarlama yapmasına pozitif katk1 sağlar (Janom vd., 2014:77).Hem firmanın hem de müşterilerinin güvenlik unsurları, internete kolay ve ekonomik erişim gibi faktörler firmaların eticaret yapabilme yeteneğini doğrudan etkilemektedir (Eid, vd, 2006:204). Web'in gelişimi, kablo ve uydu TV'nin yayılması ve telekomünikasyon ağlarının küresel bağlantısı yaşam biçimlerinin yakınlaşmasına neden olmuştur. Giderek artan ortak ihtiyaçlar ve istekler, özellikle genç orta sınıf arasında daha standart ürünler için küresel pazarlar yaratmıştır (Kotler ve Keller, 2012:606). Firmaların E-bay'in yakın zamanda satın aldığı PAYPAL gibi uluslararası ödeme hizmetleri sağlayan kuruluşlara erişimi firmaların e-ticaret yöntemini kullanmalarını etkileyen 
dış çevresel faktörlerdendir (Chaffey, vd., 2006:134). Günümüzde birçok küresel büyük şirket kendi ödeme sistemlerini geliştirmek için çaba harcamaktadır çünkü müşterilerinin kişisel bilgilerini Google ya da finans şirketleriyle paylaşmak istememektedirler (Loudon ve Traver, 2014:311). Wrigley ve Lowe (2001), teslimatın ve bir şirketin siparişleri yerine getirme kapasitesinin çevrimiçi büyümeyi etkileyen kritik bir sınırlayıcı faktör olduğunu öne sürmektedir (Chaffey, vd., 2006:503). Nakliye ve nakliye iletişimdeki teknolojik gelişmeler, şirketlerin neredeyse dünyanın her ülkesindeki pazarlara açılmalarını ve tüketicilerin alım yapmalarını kolaylaştırmıştır (Kotler ve Keller, 2012:12). İnternet kullanıcılarının güvenlik korkuları internet üzerinden ticaret yapan tüm taraflar için e-ticaretin benimsenmesinde büyük engel teşkil etmektedir (Chaffey, vd., 2006:131). Finansal güvencenin son teknolojik gelişmeler ve şirketler arasında daha yakın işbirliği ile birçok firma için daha az sorun haline gelmektedir (Eid, vd., 2006:204). Özel sektör kanunlardaki kafa karıştırıcı, çelişsili ve uzun süreçlerinden ziyade kendi uzmanlık alanlarında oluşan sorunları hızlıca belirleyip çözebilmektedirler ancak yine de dünyanın farklı ülkelerinde hükümetler internet üzerinde çevrimiçi gizlilik, verilerin korunması, suç ve sahtekârlıkları önlemek için politikalar geliştirmektedirler (Strauss ve Frost, 2014:121).

\subsection{Piyasa Güçleri}

Piyasa güçlerinin yapısı B2B e-ticaretine ilişkin firmaların tedarikçileri ve rakipleri hakkındaki e-hazırlık değerlendirmelerini ve firmalar arasındaki etkileşimi içermektedir (Janom vd., 2014:75). B2B pazarlarda alıcılar ve satıcılar birbirlerine bağlıdır ve satın alma süreci ortaklar için ek değer yaratır (Fauska vd., 2013:45). E-Ticaret firmanın tedarikçiler ve diğer iş ortaklarıly koordinasyon faaliyetlerini içermektedir (Laudon ve Price Laudon, 2012:54). İş ortaklarının baskısı firmaların B2B e-ticareti benimsemesi ve kullanımının artmasında etkilidir (Sapkiris ve Vlachopoulou, 2015:5). Tedarikçiler verimliliği arttırmak ve maliyetleri düşürmek açısından iş ortaklarına e-ticareti kullanmaları konusunda baskı uygulayabilirler (Chaffey, vd., 2006:505). Firmalar iletişim ve ödeme işlemlerini iş ortaklarıyla çevrim içi sistemler kullanarak hızlandırabilir ve maliyeti azaltabilir (Kotler ve Keller, 2012:418). E-Pazarlama yöntemi kullanan birçok firma müşteri ilişkileri yönetimi (CRM) ve iş ortağ ilişkileri yönetimi (PRM) yazılımları kullanmakta ve iş yaptıkları firmalara da bu sistemleri kullanmaları konusunda baskı yapmaktadır (Strauss ve Frost, 2014:83). Bir firma birlikte değer yaratmak için müşteri toplulukları ve iş ortaklarıyla birlikte çalışarak kendisine piyasada daha rekabetçi bir pozisyon sağlayabilir (Kotler, vd., 2017:23). Bir firmanın rakiplerinin e-pazarlama yöntemini kullanması firmanın kendisinin de e-pazarlama yöntemini kullanmasında etkili olmaktadır (Sapkiris ve Vlachopoulou, 2015:5). Firmalar arasındaki e-pazarlama alanındaki rekabet sürekli artmakta ve bu sebeple firmalar piyasada rekabet avantajı sağlamak için sürekli rakiplerini takip etmelidirler (Ponomarenko, 2018:60). Firmalar mevcut rakipleri ve piyasaya yeni giren firmaların iş modellerini takip etmeli ve rakiplerine karşı rekabet avantajı kazanmalıdır (Chaffey, vd., 2006:59). Rakip firmaların müşterilerine, tedarikçilerine ve çalışanlarına hangi teknoloji hizmetlerini sunduklarını değerlendirmeli ve bu hizmetleri kendi firmasıyla kıyaslamalı ve rakiplerinin gerisinde kalmamak için önlemler alınmalıdır (Laudon ve PriceLaudon, 2012:18).

\subsection{Hükümet}

Hükümetler e-ticaretle ilgili yasal düzenlemeler, ekonomik teşvikler, e-hizmetler, bilgi teknolojileri alt yapıları ve nitelikli iş gücünü benimseyerek firmaların e-pazarlama yöntemlerini kullanmasında önemli bir faktördür (Sapkiris ve Vlachopoulou, 2015:3-4). Hükümetin e-ticareti benimsemesi, firmalara e-ticaret konusunda ekonomik destek vermesi ve ulusal alt yap1 koşullarını sağlaması firmaların e-ticareti kullanmalarını doğrudan etkilemektedir (Janom vd., 2014:71). Hükümetin internette bilgi güvenliği ve gizlilik politikaları e-ticaretin tüm tarafları 
için önemli bir etkendir (Meng, 2012:36). Pek çok hükümet firmaların ihracatını arttırmak için ihracatı geliştirme yöntemlerine sponsorluk yapmaktadır (Kotler, 2001:378). Hükümetler firmaların uluslararası ticarete katılmaları için e-ticareti kullanmalarını teşvik eder ve hükümetlerden alınan teşvikler firmalara ihracat yapma konusunda güven verir (Chaffey, vd., 2006:138). Uluslararası e-ticaret yapmak isteyen firmalar için hedef ülkedeki hükümetin internet içeriğine yönelik tutumu ve hedef ülkedeki e-pazarlama şirketlerinin firmaların e-ticaret yapabilmesi için önemli bir faktördür (Ramonıenè, vd., 2015:94).

\section{YÖNTEM}

Araştırmanın amacına istinaden Gaziantep ayakkabı sektöründe üretim yapan firmaların epazarlama uygulamalarını kullanma durumlarını tespit etmek ve Gaziantep ayakkabı sektöründeki uluslararası e-ticaretin artırılmasına yol göstermek için nitel araştırmalarda sıklıkla kullanılan açık uçlu sorularla yüz yüze mülakat/görüşme tekniği uygulanmıştır. Nitel araştırma; insanların deneyimler ve gerçeklikler hakkında geniş kapsamlı açık uçlu sorular yoluyla insanların düşüncelerini anlamamıza katkı sağlayacak zengin ve betimleyici verilerin ortaya çıkarılması şeklinde tanımlanabilir (Arastaman vd., 2018:42). Araştırmada literatürden elde edilen kavramlar çerçevesinde firmaların uluslararası e-pazarlama sorunlarını belirlemeye yönelik katılımcılardan bilgi toplanması amacıyla katılımcılara açık uçlu sorular yöneltilmiştir. Açık uçlu sorularla yapılan nitel araştırmalarda araştırılan konu hakkında bilgi toplanması sağlanır. Bu maksatla nitel araştırmalarda açık uçlu sorularla görüşmecinin genel ve soyut düşünceleri değil sadece araştırma konusundaki düşünceleri tespit edilmedir (Gürbüz ve Şahin, 2017:428).

Araştırmada literatürden elde edilen kavramlar çerçevesinde firmaların uluslararası epazarlama sorunlarını belirlemeye yönelik katılımcılardan bilgi toplanması amacıyla Gaziantep ayakkabı sektörünün uluslararası B2B e-pazarlama sorunlarını belirlemeye yönelik sorulacak soruları netleştirebilmek için literatür araştırması sonucu Saprikis ve Vlachopoulou (2015) “'KOBİ'lerin E-Pazaryeri Kullanım Düzeyini Etkileyen Faktörler', Janom vd. (2014) 'B2B ETicaret Olgunluk Düzeyi", Ramonıenė vd. (2015) "Bütünleştirici Uluslararasılaşma”, ve Eid vd. (2006) "Kritik Başarı Faktörleri" çalışmalarındaki anket ve ölçekler incelenerek Tablo 1 'deki açık uçlu sorular geliştirilmiştir.

Tablo 1. Uluslararası B2B E-Pazarlama Kullanım Düzeyini Ölçmeye Yönelik Sorular

\begin{tabular}{|c|c|}
\hline & Uluslararası B2B E-Pazarlama Kullanım Düzeyi \\
\hline \multirow{3}{*}{$\begin{array}{l}\text { Deneme } \\
\text { Aşamasi }\end{array}$} & Uluslararası B2B e-pazarında kayıtlı bulunmaktayız, ancak hala kullanışlılığını arıyoruz. \\
\hline & Uluslararası B2B e-pazarlama yöntemi ile neredeyse hiç işlem yapmadık. \\
\hline & $\begin{array}{l}\text { Firma için yararlılıklarını belirlemek amacıyla Uluslararası B2B e-pazar hizmetlerinin artılarını ve } \\
\text { eksilerini değerlendiriyoruz. }\end{array}$ \\
\hline \multirow{2}{*}{$\begin{array}{c}\text { Düşük } \\
\text { Kullanımlı } \\
\text { Sahne }\end{array}$} & Uluslararası B2B e-pazarlama yöntemi ile birkaç işlem yaptık. \\
\hline & $\begin{array}{l}\text { Uluslararası B2B e-pazarlama ile iş yapmak hala ticari faaliyetlerimizin önemli bir parçası haline } \\
\text { gelmedi. }\end{array}$ \\
\hline \multirow{2}{*}{$\begin{array}{l}\text { Taahhüt } \\
\text { Aşamast }\end{array}$} & Gerekli olduğunda Uluslararası B2B e-pazarlama yöntemiyle işlemler yapıyoruz. \\
\hline & Uluslararası B2B e-pazarlama yöntemi ile iş yapmak, iş operasyonlarımızın önemli bir parçasıdır. \\
\hline
\end{tabular}


Literatür araştırması sonucunda firmaların B2B e-pazarlarının kullanım düzeylerine çeşitli faktörlerin etkisini değerlendirmesinin amaçlandığ firmaların B2B e-pazarlama faktörlerine ilişkin anket sorulardan yola çıkılarak uluslararası B2B e-pazarlama faktörlerine ilişkin Tablo 2'deki açık uçlu araştırma soruları geliştirilmiştir.

Tablo 2. Uluslararası B2B E-Pazarlama Faktörleri, Faktörlere İlişskin Sorular

Faktörler Faktörleri Ölçmeye Yönelik Sorular

\begin{tabular}{|c|c|}
\hline \multirow{3}{*}{$\begin{array}{l}\text { E-Pazarlama } \\
\text { Stratejisi }\end{array}$} & Firmanızın, üst yönetimi ihracata yönelik B2B e-pazarlama hakkında ne düşünmektedir? \\
\hline & Firmanızın ihracata yönelik B2B (toptan) e-pazarlama yöntemi ile ilgili stratejik hedefleri nelerdir? \\
\hline & $\begin{array}{l}\text { Firmanızın organizasyon yapısının uluslararası B2B e-pazarlama yöntemini uygulayabilmesinin } \\
\text { firmanıza katkıları hakkında düşünceleriniz nelerdir? }\end{array}$ \\
\hline \multirow{3}{*}{ Fonlar } & $\begin{array}{l}\text { Firmanızda uluslararası B2B e-pazarlama konusunda uzman personel istihdam etme konusunda } \\
\text { düşünceleriniz nelerdir? }\end{array}$ \\
\hline & $\begin{array}{l}\text { Firmanız mevcut personellerine uluslararası B2B e-pazarlama konusunda dışarıdan eğitim ve } \\
\text { danışmanlık desteği satın alınması hakkında ne düşünüyorsunuz? }\end{array}$ \\
\hline & $\begin{array}{l}\text { Firmanızın uluslararası B2B e-pazarlama konusunda dışarıdan teknik destek satın alması konusunda } \\
\text { ne düşünüyorsunuz? }\end{array}$ \\
\hline \multirow{4}{*}{$\begin{array}{c}\text { Örgütsel } \\
\text { E-Hazırlık }\end{array}$} & $\begin{array}{l}\text { Firmanızın uluslararası B2B e-pazarlama yöntemi için bilgi teknolojisi kaynakları sağlama } \\
\text { hazırlıkları nelerdir? }\end{array}$ \\
\hline & $\begin{array}{l}\text { Firmanızın çalışanlarına uluslararası B2B e-pazarlama yöntemini kullanmaları için teşvik sağlama } \\
\text { konusunda ne düşünmektesiniz }\end{array}$ \\
\hline & $\begin{array}{l}\text { Firmanız uluslararası B2B e-pazarlama yöntemi için gerekli olan mali kaynak sağlama hakkında } \\
\text { düşünceleriniz nelerdir? }\end{array}$ \\
\hline & Firmanızda çalışan personellerin uluslararası B2B e-pazarlamayla ilgili deneyimleri nelerdir? \\
\hline \multirow{4}{*}{$\begin{array}{l}\text { Destekleyen } \\
\text { Endüstriler }\end{array}$} & $\begin{array}{l}\text { Firmanızın uluslararası B2B e-pazarlama yapabilmesi için telekomünikasyon endüstrisinin sağladığı } \\
\text { hizmetler hakkında ne düşünmektesiniz? }\end{array}$ \\
\hline & $\begin{array}{l}\text { Finans sektörünün internetten yapılan satışlar için sağladığı ödeme hizmetleri hakkında ne } \\
\text { düşünüyorsunuz? }\end{array}$ \\
\hline & $\begin{array}{l}\text { Lojistik sektörünün firmanızın uluslararası B2B e-pazarlama yapabilmesi için sağladığı hizmetler } \\
\text { hakkında düşünceleriniz nelerdir? }\end{array}$ \\
\hline & $\begin{array}{l}\text { Sektördeki meslek kuruluşlarının uluslararası B2B e-pazarlamayla ilgili sağladıkları destekler } \\
\text { hakkında ne düşünüyorsunuz? }\end{array}$ \\
\hline \multirow{2}{*}{$\begin{array}{l}\text { Piyasa } \\
\text { Güçleri }\end{array}$} & $\begin{array}{l}\text { İş ortaklarınızın internet üzerinden ticari işlemler gerçekleştirmeleri hakkındaki düşünceleriniz } \\
\text { nelerdir? }\end{array}$ \\
\hline & $\begin{array}{l}\text { Rakiplerinizin internet üzerinden ticari işlemler gerçekleştirmeleri hakkındaki düşünceleriniz } \\
\text { nelerdir? }\end{array}$ \\
\hline \multirow{3}{*}{ Hükümet } & $\begin{array}{l}\text { Hükümetin uluslararası B2B e-pazarlama konusunda teşvik sağlaması hakkındaki ne } \\
\text { düşünmektesiniz? }\end{array}$ \\
\hline & $\begin{array}{l}\text { Hükümetin uluslararası B2B e-pazarlama konusunda eğitim ve danışmanlık sağlaması hakkında ne } \\
\text { düşünmektesiniz? }\end{array}$ \\
\hline & $\begin{array}{l}\text { Hükümetin uluslararası B2B e-ticaret işlemleri için güvence sağlaması hakkında ne } \\
\text { düşünmektesiniz? }\end{array}$ \\
\hline
\end{tabular}


Araştırmanın amacına istinaden oluşturulan görüşme formlarındaki soruların katılımcılara yöneltilerek görüşlerinin alındığı ses kayıtlarının bilgisayar ortamında MAXQDA veri analiz programına aktarılarak betimsel analizi yapılmıştır. Betimsel analiz dört aşamadan oluşur bu aşamalar sırasıyla betimsel analiz için araştırmanın kavramsal çerçevesi oluşturulur, tematik çerçeveye göre elde edilen verilerin kodlamasını yapılır, kodlamalar sonucunda elde edilen bulgular tanımlanır ve son olarak elde edilen bu bulgular yorumlanır (Yıldırım ve Şimşek, 2018:41-240).Nitel araştırmalarda araştırmanın geçerlik ve güvenirliğini sağlama konusunda geçerlik için inandırıcılık ve aktarılabilirlik, güvenirlik için tutarlık ve teyit edilebilirlik kavramları kullanılmaktadır (Yıldırım ve Şimşek, 2018:27).

Araştırmanın örneklemi oluşturulurken nitel araştırmalarda sıklıkla kullanılan amaçlı örnekleme yöntemlerinden ölçüt örnekleme yöntemi kullanılmıştır. Amaçlı örnekleme yoluyla araştırma konusuna zengin içerik sağlayacak durumların derinlemesine çalışılmasına olanak verir. Ölçüt örnekleme yönteminde önceden belirlenmiş ölçütler belirlenir ve bu ölçütler çerçevesinde örneklem belirlenir (Yıldırım ve Şimşek, 2018:121-122). Araştırmanın evrenini Gaziantep'in Türkiye ayakkabı sektöründe önemli bir yer teşkil etmesinden dolayı Gaziantep ayakkabı sektöründe üretim yapan firmalar oluşturmaktadır. Araştırmanın örneklemi ise ölçüt örnekleme yöntemine göre Güneydoğu İhracatçılar Birliğine kayıtlı 366 firma içerisinden 10 yıl ve üzeri süredir Güneydoğu ihracatçılar birliğine kayıtlı olan 20 firma belirlenmiş ancak 3 firmanın görüşme yapmayı kabul etmesi sebebi ile 17 firma ile oluşturulmuştur.

Nitel araştırmanın içsel geçerliğini sağlamak için katılımcılarla uzun süreli etkileşim sağlanmalı, derinlik odaklı veri toplanmalı, çeşitleme, uzman incelemesi ve katılımcı teyidi yapılmalıdır. Araştırma sonuçlarına ilişkin aktarılabilirliğin artırılması için araştırma hakkında ayrıntılı betimleme ve amaçlı örnekleme yapılmalıdır (Başkale, 2016:26). Oluşturulan araştırma formundaki sorular 21/02/2019 ile 25/03/2019 tarihleri arasında Gaziantep ayakkabı sektöründe üretim yapan ihracatçılar birliğine kayıtlı on yaş ve üzeri 17 firmaya uygulanmıştır. Katılımcılarla bire bir yapılan görüşmeler ortalama 10 ile 20 dakika sürmüştür. Yüz yüze yapılan tüm görüşmeler ses kayıt cihazı ile kayıt edilmiştir. Firmalarla yapılan görüşmeler 21/02/2019 ile 25/03/2019 tarihleri arasında saat 09:00 ile 17:00 saatleri arasında yapılmıştır. Katılımcılarla yapılan görüşmelerde katılımcıların sorulara içtenlikle cevap verdikleri gözlenmiştir. Araştırmanın analizinde katılımcıların isimleri belirtilmeyip katılımcılara ait kodlama tekniği kullanılmıştır. Yapılan pilot görüşmeler ve literatür taraması sonucunda B2B e-pazarlama sorunlarını belirlemeye yönelik 6 faktöre ilişkin 19 sorunun yer almasının uygun olacağı tespit edilmiştir. Böylece toplam 19 soruluk bir açı uçlu araştırma formu elde edilmiştir. Yapılan yüz yüze görüşmeler sırasında sorular içerisindeki katılımcıların anlayamadıkları B2B, strateji, gibi terimler hakkında bilgi verilmiş ve ayrıca katılımcılara görüşme sırasında gerektiğinde "Biraz daha detaylı ifade edermisiniz", "Başka şekilde nasıl ifade edebilirsiniz" gibi sorularla elde edilen veriler genişletilerek desteklenmiştir.

Tutarlılığın sağlanması için tutarlılık incelemesi yapılması önerilmektedir (Yıldırım ve Şimşek, 2018:282-283). Araştırma süresince verilerin toplanması tüm katılımcılara aynı görüşme formu uygulanmış ve ses kayıtları alınmıştır. Analiz sürecinde ise tüm veriler MAXQDAveri analiz programı ile kodlanmış ve analiz edilmiştir.Araştırma süresince elde edilen veriler uzman bir araştırmacı tarafından incelenerek elde edilen verilerin sonuçlarının ham verilerle karşılaştırması sağlanmıştır. Ayrıca verilerin nesnelliğinin sağlanması için Miles ve Huberman'a (1994) göre aynı veriler üzerinde yapılan iki ayrı kodlama sonucunda elde edilen kodlar arasındaki farklılıklar analiz edilmelidir. İlk analizde kodlayıcılar arası güvenilirliğin $\% 70$ 'ten daha yüksek olması beklenmez. Ancak bu oranın \%80'e yakın olması, hatta verilerin büyüklüğüne göre \%90’dan fazla olması önerilmektedir (Miles ve Huberman, 1994).

$$
\text { Inandırlcllık(Güvenirlik) }=\frac{24}{24+4}=0,8571=\% 85
$$


Araştırmanın elde edilen verilerin ilk analizinde 28 kodlama yapılmış elde edilen verilerin ikinci kez analiz edilmesi sonucunda ise 26 kodlamada yapılarak 4 kod üzerinde görüş ayrılı̆̆ oluşmuştur ve bu oranları analiz ettiğimizde ise \%85 inandırıcılık oranına ulaşılmıştır.

\section{BULGULAR}

Araştırmada katılımcıların ve firmaların özelliklerini belirlemeye yönelik bazı sorular yöneltilmiştir. Katılımcılara yöneltilen sorular cinsiyetleri, eğitim düzeyleri, firmadaki pozisyonları, yaşları, firmaların e-pazarlama kullanım düzeyleri ve iş etkinliklerini belirlemeye yönelik sorulardır. Elde edilen bulgular Tablo 3 ’te verilmiştir.

Tablo 3. Katılımcı ve Firma Özellikleri

\begin{tabular}{|c|c|c|c|}
\hline Özellikler & & $\mathbf{F}$ & $\%$ \\
\hline \multirow{2}{*}{ Cinsiyet } & Erkek & 16 & 94,11 \\
\hline & Kadın & 1 & 5,88 \\
\hline \multirow{5}{*}{ Ĕgitim Düzeyi } & İlkokul & 5 & 29,41 \\
\hline & Ortaokul & 2 & 11,76 \\
\hline & Lise & 5 & 29,41 \\
\hline & Ön Lisans & - & - \\
\hline & Lisans & 5 & 29,41 \\
\hline \multirow{7}{*}{ Pozisyon } & Firma Sahibi & 7 & 41,17 \\
\hline & Diş Ticaret & 3 & 17,64 \\
\hline & Muhasebe & 3 & 17,64 \\
\hline & Yönetici & 1 & 5,88 \\
\hline & İşletme Müdürü & 1 & 5,88 \\
\hline & Pazarlama & 1 & 5,88 \\
\hline & Tasarımcı & 1 & 5,88 \\
\hline \multirow{4}{*}{ Yaş } & $20-30$ & 6 & 35,29 \\
\hline & $31-40$ & 4 & 23,52 \\
\hline & $41-50$ & 3 & 17,64 \\
\hline & $51-60$ & 4 & 23,52 \\
\hline \multirow{3}{*}{ E-Pazarlama Kullanım Düzeyi } & Deneme Aşaması & 17 & 100 \\
\hline & Düşük Kullanımlı Sahne & - & - \\
\hline & Taahhüt Aşaması & - & - \\
\hline \multirow[t]{2}{*}{ İş Etkinliği } & İhracat/Yurt İçi & 16 & 94,11 \\
\hline & İhracat & 1 & 5,88 \\
\hline
\end{tabular}


Gaziantep ayakkabı sektöründe GAİB'ne kayıtlı 17 firmanın uluslararası B2B e-pazarlama sorunlarını tespit etmeye yönelik yapılan görüşmelerden elde edilen veriler MAXQDA veri analiz paket programına aktarılarak Gaziantep ayakkabı sektörünün uluslararası B2B epazarlama sorunlarına yönelik kodlamalar yapılmıştır. Yapılan kodlamalar Şekil 4'te verilmiştir.

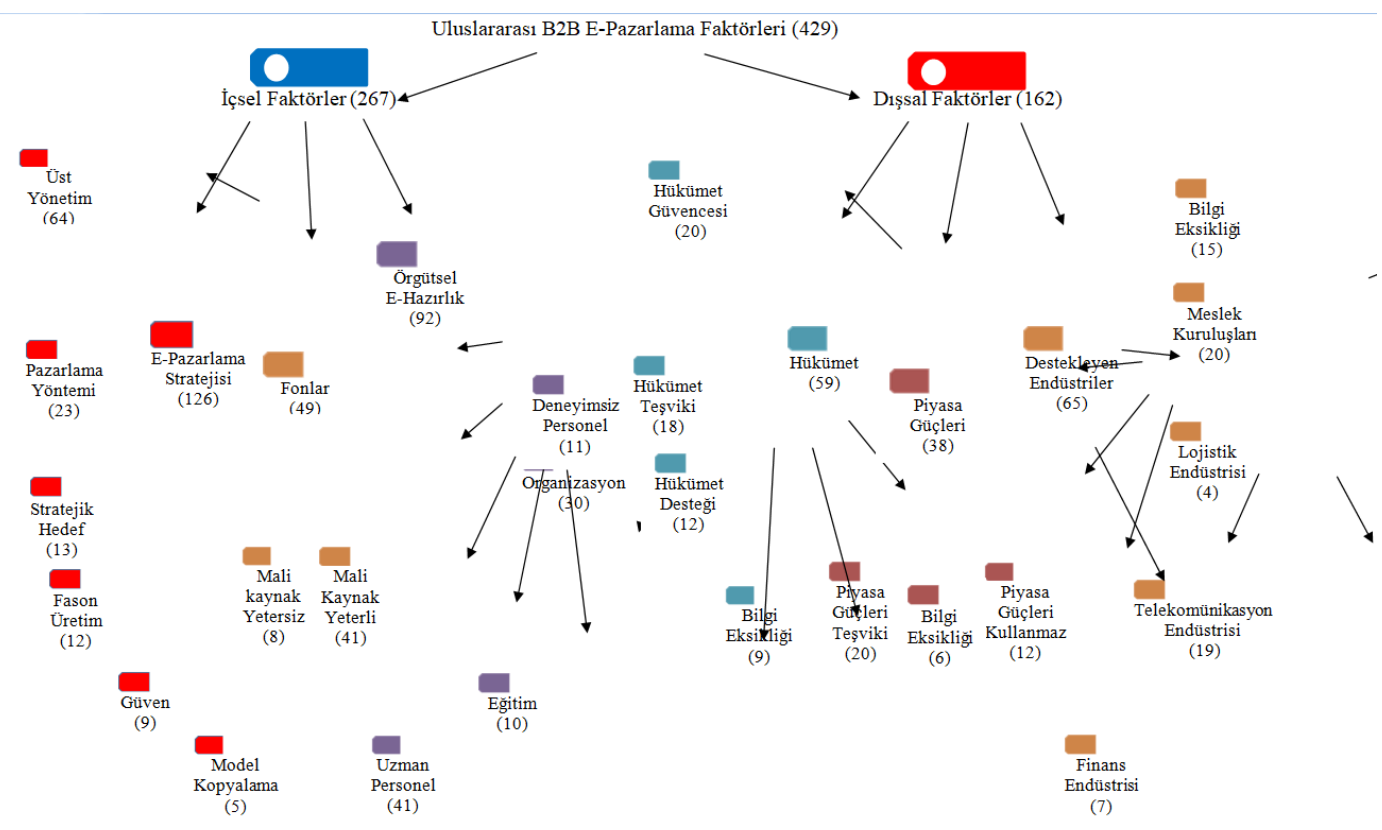

Şekil 1.Analize Genel Bakış

Gaziantep ayakkabı sektörünün uluslararası e-pazarlama sorunlarına yönelik oluşturulan literatür taramasında yola çıkılarak geliştirilen uluslararası e-pazarlama sorunlarına yönelik içsel faktörler çerçevesinde e-pazarlama stratejisi (126), fonlar (49), örgütsel hazırlık (92) faktörleri hakkında 267 kodlama, dışsal faktörler çerçevesinde ise destekleyen endüstriler (65), piyasa güçleri (38), hükümet (59) faktörleri hakkında 162 kodlama yapılarak Gaziantep ayakkabı sektörünün uluslararası B2B e-pazarlama sorunları hakkında toplam 429 adet kodlama yapılmıştır. Firmalarla yapılan görüşmeler sonucunda ortaya çıkan temalar, kategoriler ve kodlamalar Tablo 4'de verilmiştir. 
Tablo 4. Verilerin Kodlanması

\begin{tabular}{|c|c|c|c|}
\hline Temalar & Kategoriler & Kodlamalar & Frekans \\
\hline \multirow{12}{*}{ İçsel Faktörler } & \multirow{6}{*}{ E-Pazarlama Stratejisi } & Üst Yönetim & 64 \\
\hline & & Pazarlama Yöntemi & 23 \\
\hline & & Stratejik Hedef & 13 \\
\hline & & Fason Üretim & 12 \\
\hline & & Güven & 9 \\
\hline & & Model Kopyalanması & 5 \\
\hline & \multirow{2}{*}{ Fonlar } & Mali Kaynaklarımız Yeterli & 41 \\
\hline & & Mali Kaynaklarımız Yetersiz & 8 \\
\hline & \multirow{4}{*}{ Örgütsel E-Hazırlık } & Uzman Personel & 41 \\
\hline & & Organizasyon & 30 \\
\hline & & Deneyimsiz Personel & 11 \\
\hline & & Eğitim & 10 \\
\hline \multirow{12}{*}{ Dışsal Faktörler } & \multirow{5}{*}{ Destekleyen Endüstriler } & Meslek Kuruluşları & 20 \\
\hline & & Telekomünikasyon Endüstrisi & 19 \\
\hline & & Bilgi Eksikliği & 15 \\
\hline & & Finans Endüstrisi & 7 \\
\hline & & Lojistik Endüstrisi & 4 \\
\hline & \multirow{3}{*}{ Piyasa Güçleri } & Piyasa Güçleri Teşviki & 20 \\
\hline & & Piyasa Güçleri Kullanmaz & 12 \\
\hline & & Bilgi Eksikliği & 6 \\
\hline & \multirow{4}{*}{ Hükümet } & Hükümet Güvencesi & 20 \\
\hline & & Hükümet Teşviki & 18 \\
\hline & & Hükümet Desteği & 12 \\
\hline & & Bilgi Eksikliği & 9 \\
\hline
\end{tabular}

Gaziantep ayakkabı sektöründeki firmaların uluslararası e-pazarlama sorunlarını ölçmeye yönelik literatürde belirtildiği şekilde içsel ve dışsal faktörler teması altında oluşturulan epazarlama stratejisi, fonlar, örgütsel hazırlık, destekleyen endüstriler, piyasa güçleri ve hükümet kategorilerine ilişkin bulgular analiz edilecektir. 


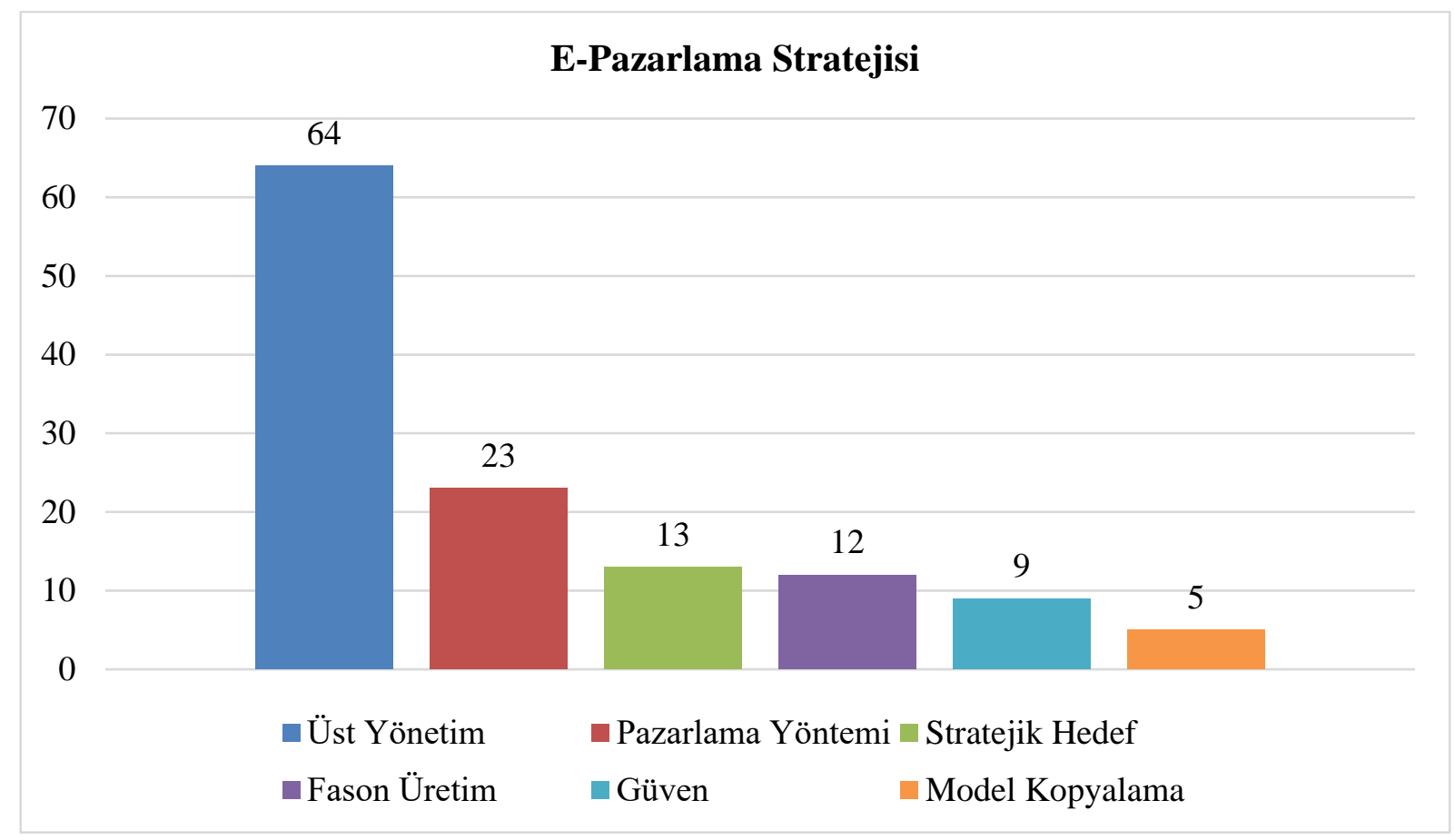

Grafik 1: Firmaların E-Pazarlama Stratejisine Yönelik Bulgular

Araştırmada firmaların e-pazarlama stratejilerine yönelik bulgular; üst yönetimin konuya olumsuz yaklaşması, pazarlama yöntemi, stratejik hedef, fason üretim, güven ve model kopyalanması kodlamaları yapılmıştır. Firmalarla yapılan görüşmelerin tamamı değerlendirildiğinde üst yönetim ile ilgili (64), pazarlama yöntemi ile ilgili (23), stratejik hedef ile ilgili (13), fason üretim ile ilgili (12), güven ile ilgili (9) ve model kopyalama ile ilgili (5) kodlama yapılmıştır. Araştırmaya katılan bazı katılımcıların görüşme kayıtlarında e-pazarlama stratejisi kategorisine yönelik şu ifadeler yer almaktadır.

F1 "Elektronik pazarlamaya yönelik bir firma değiliz firma üst yönetimi de çok olumlu bakmamaktadir."

F9"E-pazarlama konusunda teknik destek almaya bu güne kadar pek gerek görmedik. Bundan sonrada çok ihtiyaç duymayacağız biz firma olarak ürünü yapacağız müşterimizin yanına gideceğiz ya da müşteri bizim yanımıza gelecek yüz yüze birebir ürünlerimizi tanıtıp pazarlama yapacă̆ız."

F12 "Internet üzerinden pazarlamayla ilgili herhangi bir pazarlama stratejimiz bulunmamaktadır."

F12 "Firma olarak büyük markalara fason üretim yapmaktayız. Büyük markalar model gönderir bizde fiyat çalışırı fiyatta anlaşırsak markalara fason üretim yaparız."

F16 "İnternet üzerinden iletişim ve alışveriş yapalım dediğimizde müşteri tedirgin oluyor çünkü ürünü canlı olarak birebir görmek istiyorlar."

F7 “Internet üzerinden modellerimizi paylaşamıyoruz modellerimiz çalınabiliyor." 


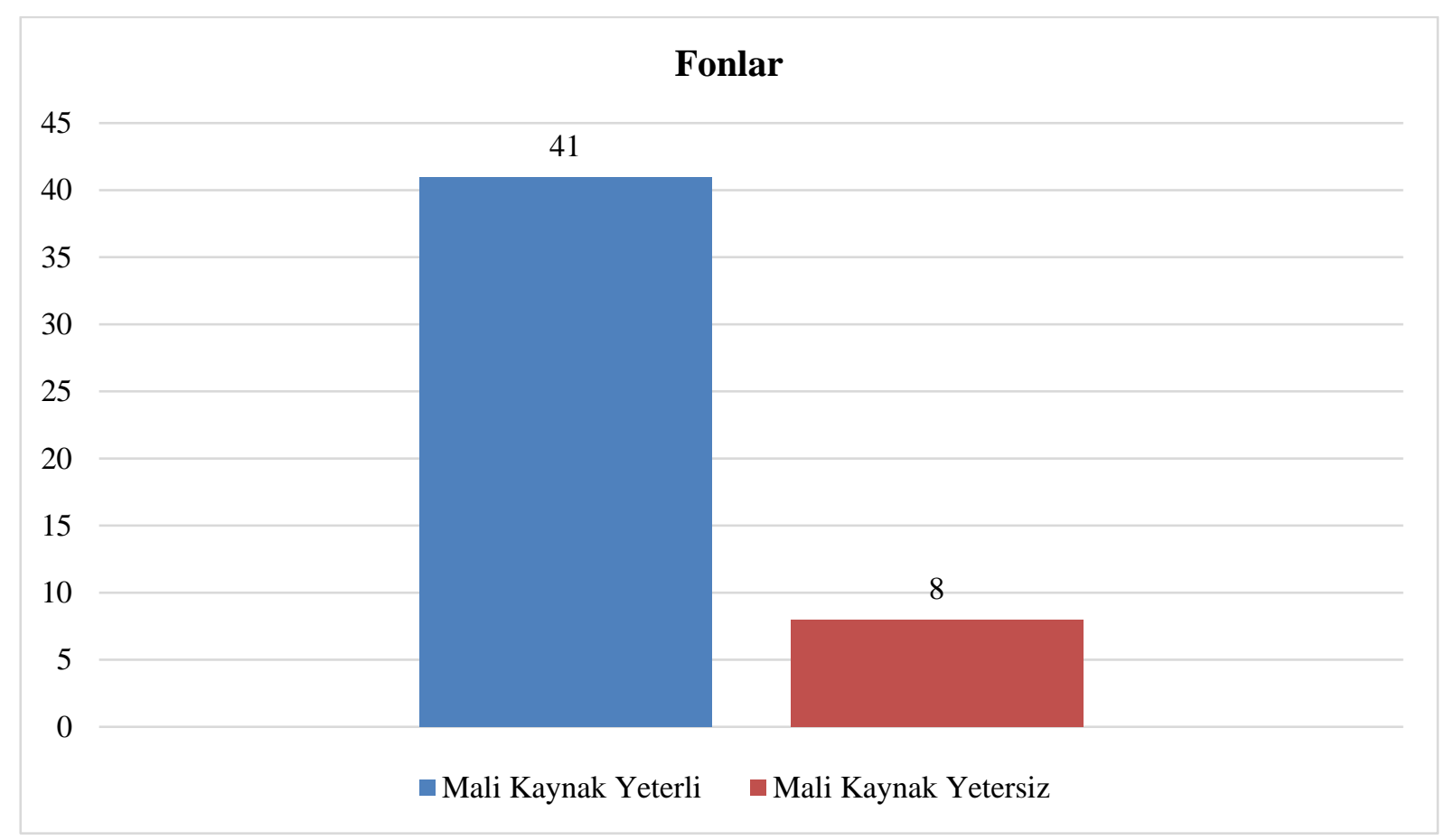

Grafik 2: Firmaların Fon Sağlamasına Yönelik Bulgular

Araştırmada firmaların e-pazarlama için fon sağlayabilme durumlarına yönelik bulgular; mali kaynaklarımız yeterli ve mali kaynaklarımız yetersiz kodlamaları yapılmıştır. Firmalarla yapılan görüşmelerin tamamı değerlendirildiğinde mali kaynaklar yeterli olması ile ilgili (41) ve mali kaynaklar yetersiz olması ile ilgili (8) kodlama yapılmıştır. Araştırmaya katılan bazı katılımcıların görüşme kayıtlarında fonlar kategorisine yönelik şu ifadeler yer almaktadır.

F5 "Internette çok zayıfiz özellikle ayakkabı sektöründe hiç kullanan yok fuarlara katıliyoruz fuarlarda satabilirsek satıyoruz onun haricinde bir pazarlama kanalımı yok. Bu sebeple gerekli teknik desteği satın alabiliriz."

F11 "Firmamız uluslararası B2B e-pazarlama konusunda dışarıdan eğitim ve danışmanlık desteği alması firmamı faydasına olacaktır ve uluslararası B2B e-pazarlama konusunda dışarıdan eğitim ve danışmanlık desteği alabiliriz."

F17"E-pazarlama konusunda düşündüklerimiz yolunda giderse firmamızda e-pazarlama konusundan sorumlu olacak uzman personel istihdam etmeyi düşünüyoruz. Çünkü e-ticaret şu anda önü en açık sektör. Firmamız e-pazarlama için gerekli kaynă̆ı sağlayacak durumda gerektiğinde e-pazarlama için gerekli mali kaynă̆ sağlarız."

F8"Sermayemizin tümünü atölyemizde internet üzerinden pazarlama için mali kaynak să̆layamayız."

F15 "Sermaye olursa bahsettiğimiz her şey yapllabilir büyük firmalar bu konuda her türlü mali kaynağı sağllyorlar. Biz gerekli mali kaynak sağlamak isteriz ama şu anda yeterli mali kaynağ sağlayacak durumda değiliz." 


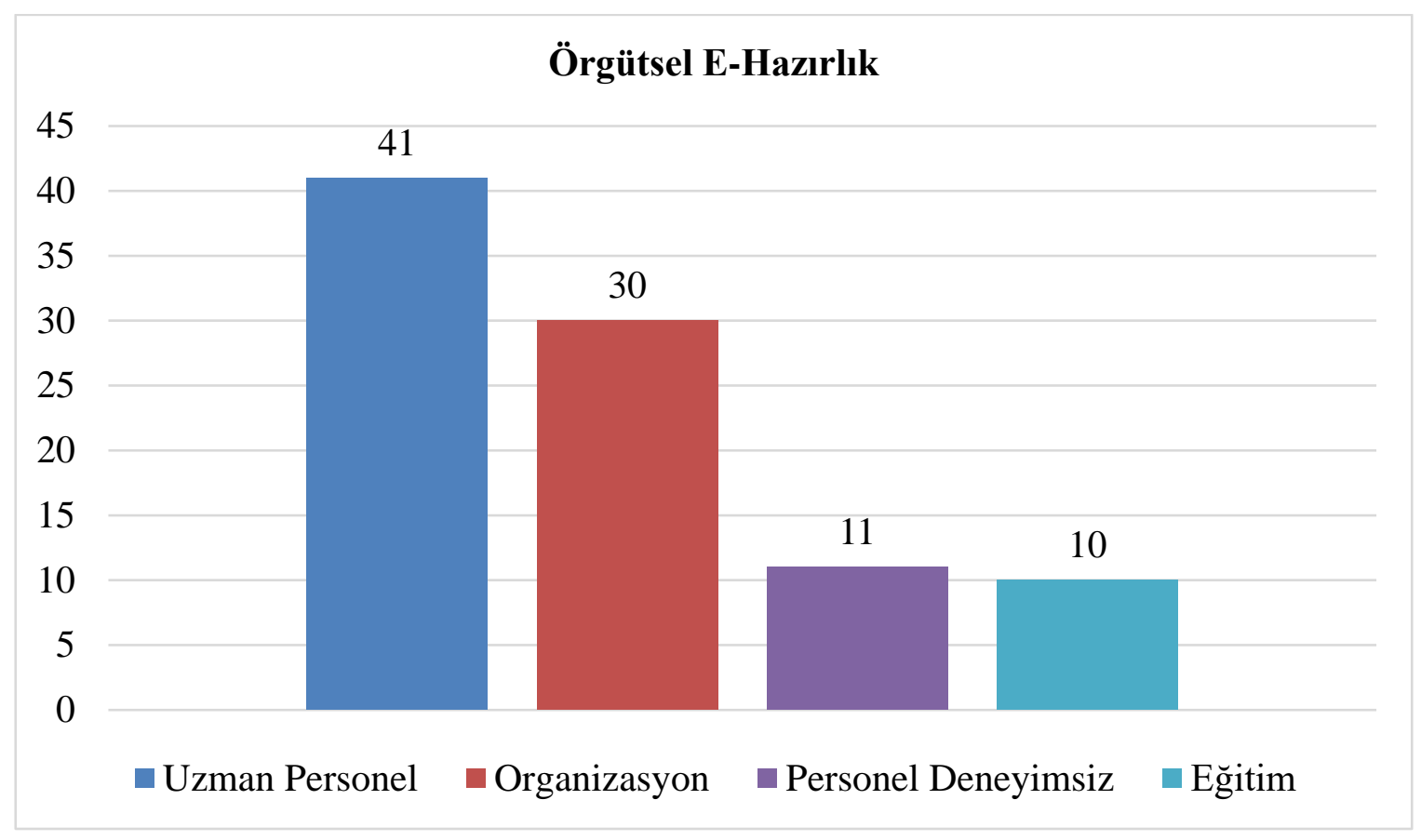

Grafik 3:Firmaların Örgütsel E-Hazırlığına Yönelik Bulgular

Araştırmada firmaların örgütsel e-hazırlıklarına yönelik bulgular; uzman personel, organizasyon, personel deneyimsiz ve eğitim kodlamaları yapılmıştır. Firmalarla yapılan görüşmelerin tamamı değerlendirildiğinde uzman personel ile ilgili (41), organizasyon ile ilgili (30), personel deneyimsiz ile ilgili (11), ve eğitim ile ilgili (10) kodlama yapılmıştır. Araştırmaya katılan bazı katılımcıların görüşme kayıtlarında örgütsel e-hazırlık kategorisine yönelik şu ifadeler yer almaktadır.

F11 "Firmamiz uluslararası B2B e-pazarlama konusunda uzaman personel istihdam etme konusunda olumlu düşünmektedir. Uluslararası B2B e-pazarlama konusunda uzman personele ihtiyaç duymaktayız."

F16"Bizim dijital alt yapımız ve organizasyonumuz olmadığ için internet üzerinden pazar araştırmast ve pazarlama yapamıyoruz. Bugün en büyük reklam internet üzerinden yapıllyor ve internet ile firma dünyanın öbür ucunda da olsa ulaşılabiliyor. Biz reklam ve pazarlamamızı yapamadığımızdan dolayı ürünlerimizin kalitesini tanıtamıyoruz. Bizim dijital ortamlarda kendimizi tanıtarak en uç noktalara erişmemiz lazım alt yapımız olmadığından dolayı yada önümüzde örnek bir done olmadiğından dolayı yani bir firma yapmış olsa bizde o firmaya bakarak o yoldan hareketle bizde yapabiliriz."

F3 "Eğitim ve danışmanlık hizmeti almak isteriz ama şu andaki mevcut personellerimiz bu eğitimi alabilecek kapasitede değiller çünkü çoğu personelimiz 40 yaş üzerinde çoğu ilkokul mezunu mümkün değil e-ticareti ögretemeyiz.” 


\section{Destekleyen Endüstriler}

25

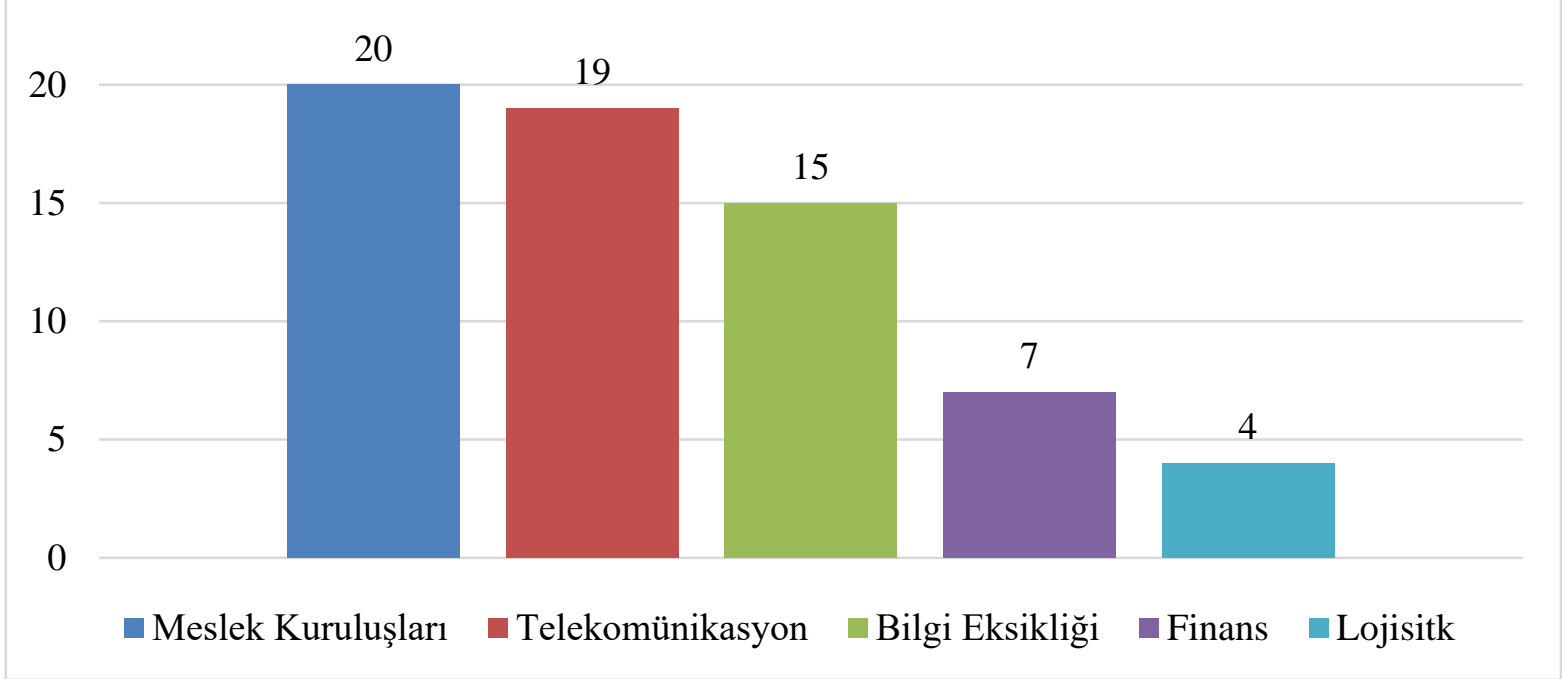

Grafik 4:Firmaları Destekleyen Endüstrilere Yönelik Bulgular

Araştırmada firmaları uluslararası e-pazarlama konusunda destekleyen endüstrilere yönelik bulgular; meslek kuruluşları, telekomünikasyon endüstrisi, bilgi eksikliği, finans endüstrisi ve lojistik endüstrisi kodlamaları yapılmıştır. Firmalarla yapılan görüşmelerin tamamı değerlendirildiğinde meslek kuruluşları ile ilgili (20), telekomünikasyon ile ilgili (19), bilgi eksikliği ile ilgili (15), finans ile ilgili (7) ve lojistik ile ilgili (4) kodlama yapılmıştır. Araştırmaya katılan bazı katılımcıların görüşme kayıtlarında destekleyen endüstriler kategorisine yönelik şu ifadeler yer almaktadır.

F10"Sektördeki meslek kuruluşları e-pazarlama konusunda herhangi bir destek sağlamamakta."

F10"Telekomünikasyon endüstrisinin firmamiza e-pazarlama konusunda herhangi bir destek sağlamamaktadırlar. Telekomünikasyon endüstrisinin e-pazarlama konusunda destek vermesi iyi olur, örneğin Türk Telekomun e-pazarlama hizmeti olsa ve bizde ürünlerimizi Türk Telekom üzerinden firmamızın reklamların yapabilmemiz firmamız için iyi olur."

F1 “Finans sektörünün e-pazarlamayla ilgili destekleri hakkında bilgi sahibi değiliz."

F8 "Şu anda yurt dışı ihracatımı bulunmadĭ̆ için son zamanlarda lojistik firmalarının bu konuda sağladiğı destekler hakkında pek bilgimiz yok."

F8“Meslek kuruluşlarının sağladı̆̆ destekler hakkında bilgimiz yok. Ama bu konuda destek sağlasalar ürün satışımız artar."

F11 "Finans sektörünün internet üzerinden sağladı̆̆ destekleri zaylf bulmaktayız. Bankaların ödeme hizmetleri masraf kesintileri yüksek ve hızl ödeme alamıyoruz. İnternet üzerinden satış yapabilmemiz için sağladıkları herhangi bir destekte yoktur." 


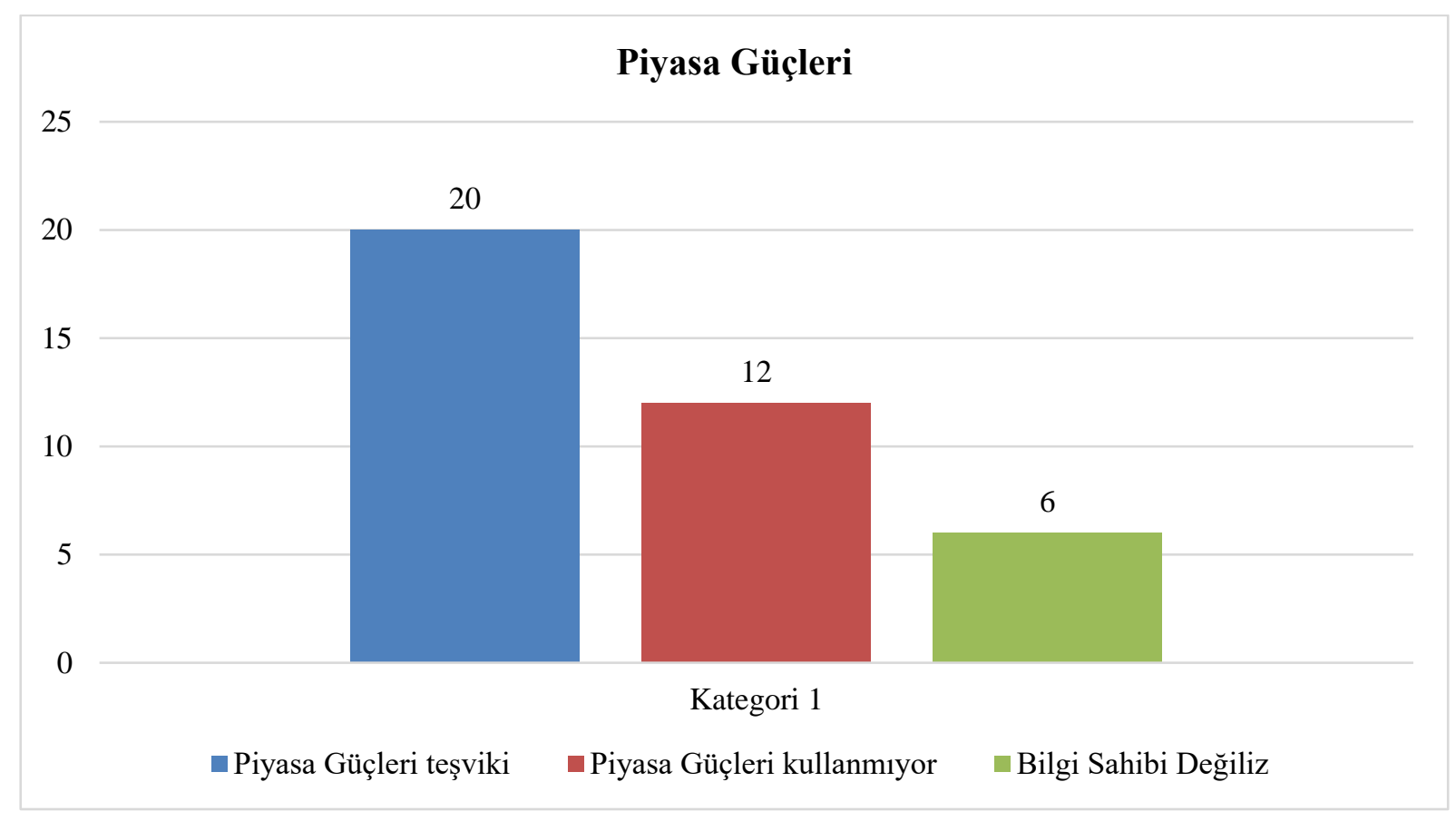

Grafik 5: Firmaları Etkileyen Piyasa Güçleri Faktörlerine Yönelik Bulgular

Araştırmada firmaları uluslararası e-pazarlama konusunda teşvik eden piyasa güçlerine yönelik bulgular; piyasa güçleri teşvik eder, piyasa güçleri kullanmıyor ve bilgi sahibi değiliz kodlamaları yapılmıştır. Firmalarla yapılan görüşmelerin tamamı değerlendirildiğinde piyasa güçleri teşviki ile ilgili (20), piyasa güçleri kullanmıyor ile ilgili (12) vebilgi sahibi değiliz ile ilgili (6)kodlama yapılmıştır. Araştırmaya katılan bazı katılımcıların görüşme kayıtlarında piyasa güçleri kategorisine yönelik şu ifadeler yer almaktadır.

F1 "Firma olarak kullanacak olsak çok güzel bir sistem olur iş ortaklarımızın internet üzerinden ticari işlemler gerçekleştirmeleri zaman ve maliyet açısından bizim avantajımıza olur iş ortaklarımızın yaptığı bu işlemler bizim firmamızın üst yönetimi için örnek teşkil eder ve üst yönetimde e-ticarete olumlu bakabilir."

F11 "İş ortaklarımızın internet üzerinden işlemler yapmaları Firmamızı da uluslararası B2B epazarlama konusunda teşvik etmektedir."

F16"Sektörümüzde bu konuda Gaziantep'te e-pazarlama yapan firma bulunmamakta İstanbul'da e-pazarlama yapan birkaç toptancı firma var toptancllar e-pazarlama konusunda imalatçılara göre hızlı davrandılar ve şuan iyi bir noktaya getirdiler."

F4"Rakiplerimizin internet üzerinden ticari işlem gerçekleştirmeleri hakkında pek bilgi sahibi değiliz."

F8 "İş ortaklarınızın internet üzerinden ticari işlemler gerçekleştirmeleri hakkında bir fikrimiz yok." 


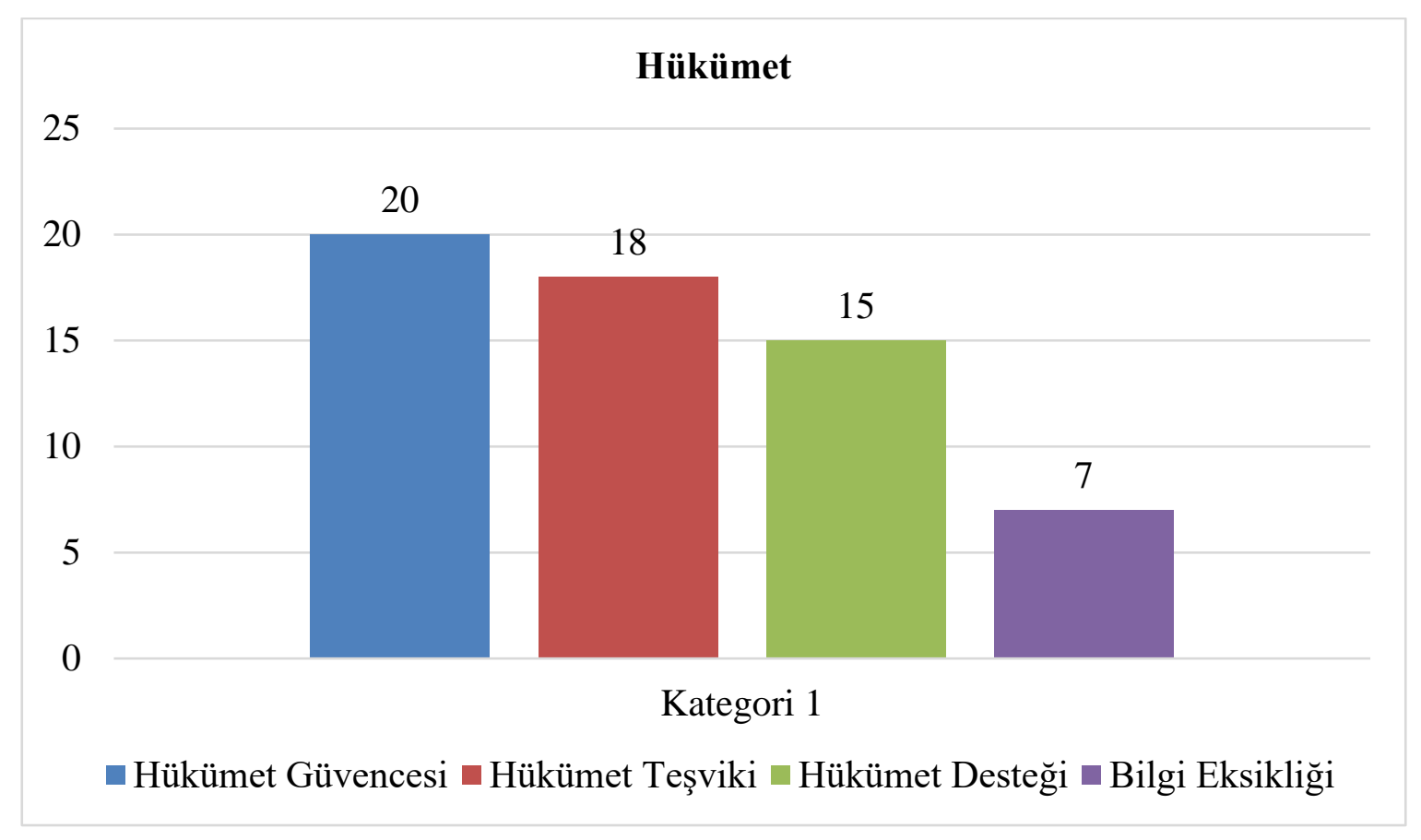

Grafik 6: Firmalara Hükümet Faktörlerinin Etkisine Yönelik Bulgular

Araştırmada firmaları uluslararası e-pazarlama konusunda hükümetin destek ve teşviklerine yönelik bulgular; hükümet güvencesi, hükümet teşviki, hükümet desteği ve bilgi eksikliği kodlamaları yapılmıştır. Firmalarla yapılan görüşmelerin tamamı değerlendirildiğinde hükümet güvencesi ile ilgili (20), hükümet teşviki ile ilgili (18) ve bilgi eksikliği ile ilgili (7) kodlama yapılmıştır. Araştırmaya katılan bazı katılımcıların görüşme kayıtlarında hükümet kategorisine yönelik şu ifadeler yer almaktadır.

F16"E-ticaret yapmadiğımı için sağladı̆̆ı güvence hakkında bilgimiz yok şimdi Çin'e baktığımızda devlet imalat yapan sektöre daha çok teşvik veriyor kredi veriyor ve sanayiciyi teşvik ediyor. Bu sistemde gelişmeler sağlanmazsa sanayiciye üreticiye destek verilmezse tüketim toplumuna dönüşeceğiz hükümet her konuda üreticiye teşvik ve güvence sağlamall."

F17"Hükümetin e-pazarlama konusunda teşvik sağlaması henüz emekleme aşamasında devlet öyle bir teşvik sağlamalı ki domino etkisi yaratmalı neredeyse tüm firmaların internet sitesi var ama etkin değil devlet bu konuda teşvikini arttırmalı."

F17"Hükümet e-pazarlama konusunda tüm işletmelere birebir eğitim ve danışmanlık sağlayamayabilir ama her sektör için bir uzaman ekip kurup firmaların e-ticaret işlemlerine yardımcı olabilir. 10 firma için bir ekip kurup firmalara eğitim ve danışmanlı hizmeti vererek e-pazarlama arttırılabilir. Devletin sağlayacağı eğitim ve danışmanlık hizmeti bizim için faydalı olur."

F1 "Hükümetin e-pazarlama konusunda teşvik sağlaması hakkında bilgi sahibi değilim."

F10 "Ĕ̆er ĕgitim ve danışmanlık hizmetleri varsa da haberdar değiliz."

F15 "Hükümetin sağladı̆ğ güvence hakkında bilgimiz yok".

F15 "Hükümetin B2B e-pazarlama konusunda să̆ladığı teşvik hakkında bilgimiz yok." 


\section{SONUÇ VE ÖNERILER}

Araştırmada firmalarla yapılan görüşmelerde firmalara yöneltilen uluslararası B2B epazarlama kullanım düzeylerini ölçmeye yönelik yarı yapılandırılmış sorulara verdikleri cevaplar incelendiğinde firmaların tamamının deneme aşamasında olduğu ve e-pazarlama yöntemini daha önce hiç kullanmadıkları sonucuna ulaşılmıştır.

Firmalarla yapılan görüşmelerden elde edilen verilerin analizi sonucunda e-pazarlama stratejisi kategorisi altında 126 kodlama yapılmış ve yapılan kodlamalar incelendiğinde; firmaların üst yönetimlerinin B2B e-pazarlamaya olumsuz yaklaştığ sonucuna ulaşılmıştır. Sapkiris ve Vlachopoulo (2015), Hijazi ve Strannhage (2016), Fauska vd. (2013), Eid vd. (2006) yapmış oldukları çalışmalarda firmaların üst yönetimlerinin e-pazarlama yöntemine karşı tutumlarının firmaların e-pazarlama yöntemini kullanmalarında önemli bir faktör olduğunu belirtmiş̧lerdir. Araştırmada firmaların büyük markalara fason üretim yaptıkları için e-pazarlama yöntemini kullanmaya ihtiyaç duymadıkları sonucuna ulaşılmıştır. Şekeroğlu (2010) yapmış olduğu araştırmada sektördeki firmaların fason üretim yaptıkları ve bu sebeple e-pazarlama yöntemini kullanmadıkları sonucuna ulaşmıştır. Araştırmada firmaların internet üzerinden yapılan işlemlere güvenmedikleri sonucuna ulaşılmıştır. Hijazi ve Strannhage (2016), Meng (2012) veEid vd. (2006) yapmış oldukları çalışmalarda e-ticaret uygulamalarında güven ve güvenirliğin önemli olduğunu belirtmişlerdir. Araştırmada firmaların e-pazarlamaya yönelik stratejik hedeflerinin olmadığı sonucuna ulaşılmıştır. Sapkiris ve Vlachopoulo (2015) ve Fauska vd. (2013) yapmış oldukları çalışmalarda firmaların stratejik hedeflerinin e-pazarlama yönteminin kullanımında önemli olduğunu belirtmişlerdir.

Firmalarla yapılan görüşmelerden elde edilen verilerin analizi sonucunda firmaların uluslararası B2B e-pazarlama yöntemi için fonlar kategorisi altındaki 49 kodlama incelendiğinde; Firmalar B2B e-pazarlama için mali kaynak sağlayabileceklerini ifade etmişlerdir. Ancak yapılan görüşmelerde e-pazarlamayla ilgili birçok konuda bilgi sahibi olmadıklarını ifade etmelerinden yola çıkarak uluslararası B2B e-pazarlama yönteminin maliyeti hakkında bilgi sahibi olmadıkları sonucu da çıkarılabilir. Şekeroğlu (2010) yapmış olduğu araştırmada ayakkabı sektörünün sermaye ve kaynak sorunları olduğu sonucuna ulaşmıştır.

Firmalarla yapılan görüşmelerden elde edilen verilerin analizi sonucunda firmaların uluslararası B2B e-pazarlama yöntemi için örgütsel e-hazırlıkları kategorisi altındaki 92 kodlama incelendiğinde; Araştırmada firmaların uluslararası B2B e-pazarlama yöntemi için örgütsel ehazırlıklarının yetersiz olduğu sonucuna ulaşılmıştır. Sapkiris ve Vlachopoulo(2015) yapmış oldukları çalışmada firmaların B2B e-pazarlama konusunda örgütsel e-hazırlığın önemli olduğunu belirtmişlerdir.Firmalarla yapılan görüşmelerde sektörde uluslararası B2B e-pazarlama konusunda uzman personel olmadığı sonucuna ulaşılmıştır. Şekeroğlu (2010) yapmış olduğu araştırmada sektörü tanıyan ve tanitabilecek e-pazarlama konusunda uzman personel olmadığ sonucuna ulaşmıştır. Firmaların organizasyon yapılarının B2B e-pazarlama yöntemine uygun olmadığı sonucuna ulaşılmışıır. Eid vd. (2010) yapmış oldukları çalışmada firmaların organizasyon yapıları ve teknolojik alt yapılarının e-pazarlama yöntemini kullanmalarında önemli olduğunu belirtmişlerdir. Firmaların eğitim düzeylerinin uluslararası B2B e-pazarlama yöntemi için yetersiz oldukları sonucuna ulaşılmıştır. Şekeroğlu (2010) yapmış olduğu araştırmada deri sanayisindeki firmaların e-pazarlama konusunda bilgi birikimi, eğitim ve kültüre sahip olmadığ1 sonucuna ulaşmıştır.

Firmalarla yapılan görüşmelerden elde edilen verilerin analizi sonucunda firmaların uluslararası B2B e-pazarlama yöntemini kullanmalarında destekleyen endüstriler kategorisi altında yapılan kodlamalar incelendiğinde; Meslek kuruluşlarının firmalara uluslararası B2B epazarlama için verdikleri desteklerin yetersiz olduğu sonucuna ulaşılmıştır. Şekeroğlu (2010) yapmış olduğu çalışmada meslek kuruluşlarının ve üniversitelerin firmalara destek vermesi gerektiği sonucuna ulaşmıştır. Janom vd. (2014) yapmış oldukları araştırmada meslek 
kuruluşlarının verdiği desteklerin firmaların e-pazarlama yöntemini kullanmalarında etkili olduğunu belirtmişlerdir. Firmalara telekomünikasyon, finans ve lojistik endüstrisinin uluslararası B2B e-pazarlama yöntemini kullanmaları için verdikleri desteğin yetersiz olduğu sonucuna ulaşılmıştır. Janom vd. (2014) yapmış oldukları çalışmada firmalara telekomünikasyon, finans ve lojistik endüstrisinin verdiği desteklerin e-pazarlama yöntemini kullanmalarında etkili olduğunu belirtmişlerdir. Firmalarla yapılan görüşmeler sonucunda destekleyen endüstriler faktörleri hakkında bilgi sahibi olmadıkları ve bilgi edinmede sorun yaşadıkları sonucuna ulaşılmıştır. Şekeroğlu (2010) yapmış olduğu çalışmada sektördeki firmaların B2B E-pazarlamayla ilgili bilgi aktarımının yetersiz olduğu sonucuna ulaşmıştır.

Firmalarla yapılan görüşmelerden elde edilen verilerin analizi sonucunda firmaların uluslararası B2B e-pazarlama yöntemini kullanmalarında piyasa güçleri kategorisi altında yapılan kodlamalar incelendiğinde; Firmaların piyasadaki rakiplerinin ve iş ortaklarının e-iş uygulamalarını kullanmadıkları ve piyasa güçlerinin yaptıkları e-işlemler ile ilgili bilgilerinin

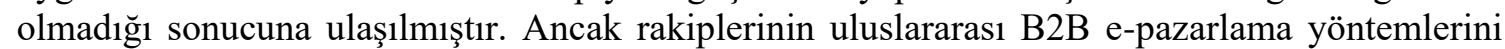
kullanmaları halinde firmaların üst yönetimlerinin uluslararası B2B e-pazarlama yöntemini kullanmaya teşvik edeceği sonucuna ulaşılmıştır. Sapkiris ve Vlachopoulo(2015) yapmış oldukları çalışmada firmaların iş ortaklarının ve rakiplerinin B2B e-pazarlama konusunda baskılarının firmaların e-pazarlama kullanım düzeyini olumlu yönde etkilediği sonucuna ulaşmışlardır. Janom vd. (2014) yapmış oldukları çalışmada iş ortakları ile yapılan e-pazarlama konusundaki işbirlikleri firmaların B2B e-pazarlama yöntemini kullanmalarında etkili olduğunu belirtmişlerdir.

Firmalarla yapılan mülakatlardan elde edilen verilerin analizi sonucunda firmaların uluslararası B2B e-pazarlama yöntemini kullanmaları için hükümet kategorisi altında yapılan kodlamalar incelendiğinde; hükümetin firmalara uluslararas1 B2B e-pazarlama konusunda yeterli güvence sağlamadığı, hükümetin konuyla ilgili teşvikinin yetersiz olduğunu, hükümetin eğitim ve danışmanlık desteği sağlamadığı sonucuna ulaşılmıştır. Şekeroğlu (2010) yapmış olduğu çalışmada devletin firmalara sağladığı destek ve teşviklerin yetersiz olduğu sonucuna ulaşmıştır. Sapkiris ve Vlachopoulo (2015) yapmış oldukları çalışmada hükümetin firmalara destek ve teşvik sağlaması gerektiği sonucuna ulaşmışlardır. Firmalarla yapılan görüşmeler sonucunda hükümetin firmalara uluslararası B2B e-pazarlama konusunda sağladığ1 güvence, teşvik ve destekler hakkında bilgi sahibi olmadıkları sonucuna ulaşılmıştır. Şekeroğlu (2010) yapmış olduğu çalışmada firmaların B2B e-pazarlama konusunda bilgi sahibi olmadıkları sonucuna ulaşmıştır.

Gaziantep ayakkabı sektöründe yaptığımız araştırma sonucunda sektörde bilgi edinmede sorunlar yaşandığı görülmekte ve sektöre uluslararası B2B e-pazarlama konusunda bilgi akışının sağlanması için üniversiteler, meslek kuruluşları ve devlet kurumları tarafindan sektöre yönelik eğitimler düzenlenmeli sektördeki firmalara bilgi akışı sağlanmalıdır.

Firmalarla yapılan görüşmeler sonucunda ayakkabı sektörünü tanıyan B2B e-pazarlama konusunda uzman personellerin yetiştirilmesi için üniversiteler, meslek kuruluşları ve devlet kurumları tarafından projeler üreterek ayakkabı sektöründeki mevcut pazarlamacılara e-iş uygulamaları eğitimleri verilmelidir.

Gaziantep ayakkabı sektöründeki firmalarınuluslararası B2B e-pazarlama stratejilerini anlayabilmesi ve uygulayabilmesi için üniversiteler, meslek kuruluşları ve devlet kurumları tarafından örnek projeler geliştirilmeli ve uygulamaya konulmalıdır.

Ayakkabı sektörünün uluslararası B2B e-pazarlama uygulamalarına alt yapı oluşturmak için lojistik, finans ve telekomünikasyon endüstrilerinin ayakkabı sektörüyle birlikte projeler geliştirerek sektöre alt yapı desteği sağlanmalıdır. 
Ayakkabı sektöründe uluslararası B2B e-pazarlama uygulamalarını kullanacak firmalara hükümet tarafından vergi teşvikleri sağlanmalı ve sektördeki firmalara e-iş uygulamalarını kullanmaları için gerekli olan güven ortamı sağlanmalıdır.

\section{KAYNAKÇA}

Akçi, Y. ve Göv, A. S. (2015). Tüketicilerin e-ticaret algılarının incelenmesi (Gaziantep ve Adıyaman örneği). Mehmet Akif Ersoy Üniversitesi Sosyal Bilimler Enstitüsü Dergisi, 13, 413-433

Arastaman, G., Öztürk, F. İ., Fidan, T. (2018). Nitel araştırmada geçerlik ve güvenirlik: Kuramsal bir inceleme. YYÜ Eğitim Fakültesi Dergisi. 15(1), 37-75 http://dx.doi.org/10.23891/efdyyu.2018.61

Başkale, H. (2016). Nitel araştırmalarda geçerlik, güvenirlik ve örneklem büyüklüğünün belirlenmesi. Dokuz Eylül Üniversitesi Hemşirelik Fakültesi Elektronik Dergisi. 9/1, 23-28

Chaffey, D., Ellis, Chadwick, F., Mayer, R., Johnston, K. (2006). Internet marketing strategy, ImplementationandPractice. PearsonEducation Limited Edinburgh GateHarlowEssex CM 202 JE England

Chong, W. Man, K.L., Zhang, N. (2011). An interoperable B2B e-commerceframeworkfor e-marketing capabilities. Engineeringletters 19/3. Liverpool University, China.

Çakıroğlu, Başar, A. G. (2013). Türk ayakkabı firmalarının rekabet stratejilerinde tasarımın rolü. Yayınlanmış Doktora Tezi, İstanbul Teknik Üniversitesi, İstanbul.

Eid, R., Trueman, M.,Ahmed, A. M. (2006). B2B international internet marketing a benchmarking exercise. Benchmarking: An International JournalVol. 13 No. 1/2, 2006 pp. 200-213. EmeraldGroup Publishing Limited 14635771, Emerald DOI 10.1108/14635770610644682

Erden, M. (2010). E-Ticaretin uluslararası pazarlamaya etkisi. Yayınlanmış Yüksek Lisans Tezi, Beykent Üniversitesi, İstanbul.

Fauska, P.,Kryvinska, N., Strauss, C. (2013)The role of e-commerce in B2B markets of goodsandservices. Article in International Journal of Services Economicsand Management January 2013 DOI: 10.1504/IJSEM.2013.051872

Gaziantep Ticaret Odas1, (2011). Ayakkabı sektör araştırma raporu. Gaziantep https://www.yumpu.com/tr/document/read/22113757/ayakkab-sektoru arastrma-raporu-gaziantep-ticaret-odas $(18.01 .2019)$

Gaziantep Sanayi Odas1, (2017). Gaziantep ayakkabı sektör raporu. Gaziantep http://www.gso.org.tr/userfiles/file/Sayfalar/Ayakkab\%C4\%B1\%20Sekt\%C3\%B6r\%C3\%BC.pdf (18.01.2019).

Gürbüz, S. ve Şahin, F. (2017). Sosyal bilimlerde araştırma yöntemleri. Ankara: Seçkin Yayınları

Hijazi, A.,Strannhage, P. (2016). Fashionjoinsthedigitalrevolution a study on theimpact of digitalisation in theswedishhigh-endfashionindustryMaster'sThesis 30 credit s Department of Business StudiesUppsalaUniversity Spring Semester of 2016

International Trade $\quad$ Center $\quad$ (ITC) (2017) https://www.trademap.org/leatherline/Country SelProduct.aspx?nvpm=1\%7c\%7c\%7c\%7c\%7c64\%7c\%7c\%7c2\%7c1 \%7c1\%7c1\%7c1\%7c\%7c2\%7c1\%7c1. (01.25.2019)

Janom, N., Zakaria, M.S., Arshad, N.H., Salleh, S.S., Aris S.R.S. (2014). Multidimensionalbusinesstobusiness ecommercematurityapplication: Assessment on itspracticality. İ-Business, 2014, 6, 71-81 Published Online June 2014 in SciRes. DOİ: 10.4236/ib.2014.62009

Kaplan, B. (2015).Uluslararası Girişimci Kobilerde E-Pazarlama Odaklılık Ve Web Sitesi Kullanımı: Küresel Doğan İşletmeler Üzerine Bir Araştırma, Marmara Üniversitesi Sosyal Bilimler Enstitüsü, İstanbul. Yayınlanmış Doktora Tezi.

Kotler, P. and Keller, K. L. (2012). Marketing management.PearsonEducation, Inc.,publishing as PrenticeHall, One Lake Street, UpperSaddleRiver, New Jersey 07458.

Kotler, P. AndPfoertsch, W. (2006). B2B brandmanagement. Springer Berlin-Heidelberg, Germany

Kotler, P. (2001). Marketing management, Milleniumedition. Prentice-Hall, Inc. A PearsonEducationCompanyUpperSaddleRiver, New Jersey 07458

Kotler, P., Kartajaya, H., Setiawan, I. (2017). Marketing 4.0: Movingfromtraditionaltodigital. Publishedby John Wiley\&Sons, Inc., Hoboken, New Jersey Published simultane ously in Canada. 
Kuru, S. ve Paksoy, A. C. (2014). Ayakkabı modası perspektifinde Kahramanmaraş çarık ve yemenilerinin yaşam seyrinin değerlendirilmesi. Motif Akademi Halkbilimi Dergisi. 1(1), 99-122

Kuşat, N. (2016). İşletmeden işletmeye (B2B) elektronik pazaryerleri ve gelişmekte olan ülkelerin diş ticaretinde uygulanabilirliği. Yönetim ve Ekonomi Dergisi, 23/3, 691-709

Laudon, Kenneth C. andTraver, C. Guercio (2014). E-Commerce business. Technology. society. PublishedbyPearsonEducation, One Lake Street, UpperSaddleRiver, New Jersey 07458.

Laudon, Kenneth C. andLaudon, Jane P. (2012). Management informationsystems: Managingthedigitalfirm. PearsonEducation, Inc.,UpperSaddleRiver, New Jersey, 07458.

Malinen, M. (2013). Strategic marketing planningforA B2B High-Techmanufacturercreating a marketing strategy. Withtheaim of securing a leadingposition in thefinnish market,LahtiUniversity of AppliedSciences,DegreeProgramme in International Business Management Master'sThesis

Meng, P. (2012). Characteristicsandpromotionresearch on fashionclothing e-marketing. Creative Education 2012. Vol.3, Supplement, 33-38 PublishedOnline December 2012 in SciRes(http://www.SciRP.org/journal/ce), DOI: $10.4236 /$ ce. $2012.37 \mathrm{~B} 008$

Miles, M. B., ve Huberman, A. (1994). Qualitativedata analysis. SagePublication, London.

Pine, B.J. (1993). Masscustomization. thenewfrontier in businesscompetition. Harvard Business School Press, USA. DOI: $\underline{10.1177 / 031289629301700206}$

Ponomarenko, A. (2018). $\quad$ B2B $\quad$ Digitalmarketing plan forattractingnewinternationalcustomersandbuildingbrandawarenessglobally. School of Business, DegreeProgramme in International Business

Ramonıenè, L.,Šukevıčıūtè, L., Škudıenè, V. (2015). Internationalizationenabledbyınternetization: E-marketing approach. Issn 1392-1142 (Print), Issn 2335-8750 (Online) OrganızacijųVadyba: S1stemınıa1Tyrıma1 2015.74 http://dx.doi.org/10.7220/MOSR.2335.8750.2015.74.6

Saprikis, V.,andVlachopoulou, M. (2015). Investigatingfactorsinfluencinguseof B2B E-market places in greekfirms: The B2B e-mark fluframework. International Journal of Business Researchand Development ISSN 1929-0977| Vol. 4 No. 1, pp. 1-24 (2015). DOI: 10.24102/ijbrd.v4i1.573

Schafer, J.B., Konstan, J., Riedl, J. (2001). E-commercerecommendationapplications. Data Miningand Knowledge Discovery. 5, 115-153

Schafer, J.B., Konstan, J., Riedl, J. (1999). Proceedings of the 1st conference on electroniccommerce(pp. 158-166). DOI: $10.1145 / 336992.337035$

Škudıenė, V., Auruškevıčınė, V., Ivanauskıenė, N., Ramonıenė, L. (2014). theinternationalizationand e-marketing adoption of emergingeconomySMES 1. International Journal of Liberal ArtsandSocialScienceVol. 2 No. 2 March, 2014.

Skudiene, $\quad$ V., $\quad$ Auruskeviciene, V., $\quad$ Sukeviciute, $\quad$ L. $\quad$ (2015) 20th internationalscientificconferenceeconomicsandmanagement. Vilnius, 01305, Lithuania. ISM University of Management andEconomics, (pp.918-924)

Strauss, J.,Frost, R. (2014). E-marketing. PearsonEducation Limited 2014

Şekeroğlu, Ö. K. (2010). Deri sanayinde e-pazarlama için yol haritası çıkarılması üzerine bir araştırma, Ege Üniversitesi Fen Bilimleri Enstitüsü, İzmir. Yayınlanmış Doktora Tezi

T.C. Ekonomi Bakanlığı. (2016). Sektör raporları ayakkabı sektörü. İstanbul: İhracat Genel Müdürlüğü Tekstil ve Konfeksiyon Ürünleri Daire Başkanlığı.

T.C. Gümrük ve Ticaret Bakanlığı Yayınları. (2017). Esnaf ve sanatkârlar özelinde sektör analizleri projesi deri, giyim ve ayakkabı sektörü. İstanbul: Mega Basım Yayın San. ve Tic. A.Ş.

Uluslararası Çalışma Örgütü (ILO). (2018). Gaziantep ayakkabı sektörü için değer zinciri analizi ve proje önerileri. Gaziantep: $\quad$ https://www.ilo.org/wcmsp5/groups/public/---europe/---ro-geneva/---iloankara/documents/genericdocument/wcms 625186.pdf(17-01-2019).

World TradeOrganizationWorld Trade Report 2018: Thefuture of World trade: How digitaltechnologiesaretransforming global commercehttps://www.wto.org/english/res_e/publications_e/wtr18_e.htm (24.12.2018)

World TradeOrganization: World $\quad$ Trade $\quad$ Statistical $\quad$ Review 2018 www.wto.org/english/res_e/statis_e/wts2018_e/wts2018_e.pdf (24.12.2018) 
Yamamoto, G.T., Bayaramoğlu, E., Yilmaz, B., Şekeroğlu, Ö. (2009). Procedingsof internationalendrepreneureshipcongress 2009: "SMES andendrepreneureship (pp. 183-191). İzmir: University of Economics

Yaşar, O. (2018). Türkiye'de ayakkabı sanayi.Akademik Sosyal Araştırmalar Dergisi, 6(69), 15-32.

Yıldırım, A. (1999). Nitel araştırma yöntemlerinin temel özellikleri ve eğitim araştırmalarındaki yeri ve önemi. Eğitim ve Bilim Dergisi. 23 (112), 7-17.

Yıldırım, A. ve Şimşek, H. (2018). Sosyal bilimlerde nitel araştırma yöntemleri. Seçkin Yayıncılık San. ve Tic. A.Ş. 


\section{Extended Summary}

\section{International B2B E-Marketing a Research for Gaziantep Footwear Sector}

In today's world, there are important developments in communication and information technologies. These developments cause radical changes in the traditional trading methods of firms. These new developments affect the most preferred export method in entering international markets. Companies are operating in overseas markets, trying to outperform their competitors. In order to operate in the international market, companies need to develop product development, pricing, distribution channels and promotional strategies suitable for international markets. For this reason, companies should determine e-commerce strategies determined in international markets according to the requirements of the age and turn them into a dynamic structure (Sürer, 2012: 1).

Gaziantep shoe sector produces with 50\% -60\% idle capacity (GTB, 2017: 23). The idle capacity of the Gaziantep shoe sector should be evaluated in international markets. For this reason, using information technologies and e-commerce methods for Gaziantep shoe industry is not an option but an obligation.

Hypotheses of this study;

- There is a relationship between Gaziantep shoe industry's use of international e-marketing methods and internal management factors.

- There is a relationship between Gaziantep shoe industry's use of international e-marketing methods and external management factors.

The purpose of this study is to reveal the situation of Gaziantep shoe industry using international e-marketing technique and e-marketing problems.

B2B in general (Business to Business); It is defined as the interaction of suppliers, distributors, agents and other companies that form customers (Fauska et al., 2013: 44). The process of companies performing services and products over the internet (B2B) is called an ecommerce model (Akçi and Body, 2015: 416).

In order for companies to make successful international e-marketing, a strong technological infrastructure and organization is required in internal management factors (Eid et al. 2006: 203). Internal factors of companies are the most important success factors of international e-marketing for companies to apply international e-marketing method (Kuşat, 2016: 697). Identifying internal and external organizational factors of companies is critical in measuring B2B e-marketing preparation levels (Janom vd., 2014: 73).

External environmental factors that are effective in international e-marketing management show the development of companies' internet marketing strategy. External environmental factors are a natural extension of the company's infrastructure within the company. External environmental factors will have no impact without sensitive and well-organized internal processes (Eid, vd., 2006:204).

In the research, open questions were developed to determine the international e-marketing problems of the companies within the framework of the concepts obtained from the literature. In the literature research, the questions to be asked to the participants to determine the international B2B e-marketing problems of the Gaziantep shoe industry; Saprikis and Vlachopoulou (2015) " Factors Affecting E-Market Place Usage Level of SMEs ", Janom et al. (2014) "B2B ECommerce Maturity Level", Ramonienı et al. (2015) "Integrative Internationalization", Eid et al. (2006) In the "Critical Success Factors" studies, open-ended questions were developed by examining the questionnaires and scales. 
Qualitative research method, which is frequently used in social sciences, was used in the research. In the research, open-ended questions were asked to the participants in order to collect information from the participants in order to determine the international e-marketing problems of the companies. In qualitative research conducted with open-ended questions, it is ensured that information is collected on the subject studied. For this purpose, in qualitative research, it is not only the general and abstract thoughts of the interviewer but only the thoughts about the research (Gürbüz and Şahin, 2017: 428).

During the research, data collection was applied to all participants, the same interview form was applied and sound recordings were taken. In the analysis process, all data were coded and analyzed with the MAXQDA data analysis program. The data obtained during the research were examined by a qualified researcher and the results of the data were compared with the raw data.

For the reliability of the study, according to Miles and Huberman (1994), the differences between the codes obtained by two separate coding on the same data should be analyzed.

$$
\text { Persuasiveness(Reliability) }=\frac{24}{24+4}=0,8571=\% 85
$$

As a result of the analysis, reliability was determined as $85 \%$.

The universe of the research is the companies producing shoes in Gaziantep shoe sector. The sample of the research was determined according to the criterion sampling method. The sample of the research; It is the 20 companies among 366 companies registered in the Southeast Exporters Association for 10 years or more. The sample of the study was created with 17 companies since 3 companies did not agree to interview.

The questions in the research form created were applied to 17 firms aged 10 years and over, registered in the exporters union producing in the Gaziantep shoe industry. One-to-one interviews with the participants took an average of 10 to 20 minutes. All face-to-face interviews were recorded with a voice recorder. Meetings were held with companies between the dates of 21/02/2019 and 25/03/2019 between 09:00 and 17:00.

Based on the literature review of Gaziantep shoe industry for international e-marketing problems, within the framework of the internal factors for the B2B international e-marketing problems of the companies;

- E-marketing strategy (126),

- Funds (49),

- Organizational preparation (92)

267 coding was done about internal management factors.

In the context of external factors;

- Supporting industries (65),

- Market Forces (38),

- The Government (59)

162 coding was done about internal management factors.

A total of 429 codings were made about the international B2B e-marketing problems of Gaziantep shoe industry. 
As a result of the analysis of the data obtained from the research, it was concluded that all companies are in the trial phase and do not use the e-marketing method.

The findings obtained as a result of face to face interviews with companies were analyzed. It is determined that there is a relationship between the internal management factors of companies and the use of B2B e-marketing method.

(1) There is no international B2B e-marketing strategy.

(2) Insufficient funds for international B2B e-marketing.

(3) There is no corporate e-preparation for international B2B e-marketing.

The findings obtained as a result of face to face interviews with companies were analyzed. It has been determined that there is a relationship between the external management factors of companies and the use of B2B e-marketing method.

(1) Supporting Sectors Insufficient for B2B e-marketing.

(2) Market forces do not use E-marketing.

(3) Support and incentives for B2B e-marketing for government firms are insufficient.

As a result of the research, recommendations for Gaziantep shoe sector are listed below;

- Universities, professional organizations and government agencies should organize training for the industry for companies in the Gaziantep Shoe sector.

- Information flow should be provided to companies in the sector.

- Existing marketing personnel should be provided with e-marketing training to meet the needs of the companies in the sector for e-marketing expert staff.

- B2B e-marketing projects should be developed and implemented by universities, professional organizations and government agencies.

- Infrastructure support should be provided to the sector by developing projects together with the shoe sector of the logistics, finance and telecommunications industries.

- Companies in the sector should be provided with tax incentives by the government on e-marketing.

- Firms in the sector should be provided with the trust environment required to use e-business applications. 
Optimum Journal of Economics and Management Sciences, Vo1. 7, No. 2- http://dergipark.org.trloptimum Ylldizhan and Yurtsever - International B2B Marketing a Research for Gaziantep Footwear Sector 